\title{
PENGARUH PENDAPATAN ASLI DAERAH DAN DANA TRANSFER TERHADAP BELANJA DAERAH KOTA JAYAPURA
}

\author{
La Ode Abdul Wahab, SE., M.Si \\ Dosen Prodi Manajemen, STIE Port Numbay Jayapura
}

\begin{abstract}
This research is a quantitative research, with time series data. The data used in this study is the realization of Jayapura City Regional Income and Expenditures for the 2010-2019 Period. This study aims to determine local revenue and transfer funds to regional expenditures in Jayapura City. To answer the problem formulation in this study, multiple linear regression was used. The results of this study indicate that local revenue has an insignificant negative effect on regional expenditures in Jayapura City. Transfer funds have a positive and significant impact on regional spending in Jayapura City. And simultaneously local revenue and transfer funds have a positive and significant effect on regional spending in Jayapura City. The value of the determinant coefficient (Adjusted $R$ Square) of 0.917 or $91.7 \%$ indicates that local revenue and transfer funds have a very large contribution to regional expenditure in Jayapura City. Or in other words, local revenue and transfer funds contribute to the influence of Jayapura City's regional expenditure by $91.7 \%$ while the rest is influenced by other variables not examined in this study.
\end{abstract}

Keywords: local revenue, transfer funds and regional expenditure

Abstrak: Penelitian ini merupakan penelitian kuantitatif, dengan data time series. Data yang digunakan dalam penelitian ini adalah data realisasi Pendapatan dan Belanja Daerah Kota Jayapura Periode 2010-2019. Penelitian ini bertujuan untuk mengetahui pendapatan asli daerah dan dana transfer terhadap belanja daerah Kota Jayapura. Untuk menjawab rumusan masalah dalam penelitian ini, maka digunakan regresi linear berganda. Hasil penelitian ini menunjukkan bahwa bahwa pendapatan asli daerah berpengaruh negatif tidak signifikan terhadap belanja daerah Kota Jayapura. Dana transfer berpengaruh positif dan signifikan terhadap belanja daerah Kota Jayapura. Dan secara simultan pendapatan asli daerah dan dana tranfer berpengaruh posifiti dan signifikan terhadap belanja daerah Kota Jayapura. Nilai koefisien determinan (Adjusted R Square) sebesar 0,917 atau sebesar 91,7\% menunjukkan bahwa pendapatan asli daerah dan dana transfer memiliki kontribusi pengaruh yang sangat besar terhadap belanja daerah Kota Jayapura. Atau dengan kata lain, pendapatan asli daerah dan dana transfer memberikan kontribusi pengaruh terhadap belanja daerah Kota Jayapura sebesar 91,7\% sedangkan sisanya dipengaruhi oleh variabel lain yang tidak diteliti dalam penelitian ini.

Kata Kunci : pendapatan asli daerah, dana transfer dan belanja daerah

\section{PENDAHULUAN \\ Latar Belakang}

Sejak dilaksanakan otonomi daerah pada tanggal 1 Januari 2001 diharapkan pembangunan di daerah berjalan seiring dengan pembangunan di pusat. Tujuan otonomi daerah antara lain menciptakan kemandirian, pendelegasian wewenang, menggali potensi sumber-sumber daya Pemerintah Daerah agar mapan secara keuangan.

Dengan diberlakukannya otonomi daerah maka pemerintah daerah dituntut untuk dapat melaksanakan fungsi dan peranannya sesuai dengan kewenangan yang dimiliki. Kebijakan pemerintah Indonesia tentang otonomi daerah tersebut dipandang sangat demokratis dan memenuhi aspek desentralisasi yang sesungguhnya. Desentralisasi sendiri mempunyai tujuan untuk lebih meningkatkan kesejahteraan dan pelayanan kepada masyarakat, pengembangan kehidupan berdemokrasi, keadilan, pemerataan, dan pemeliharaan hubungan yang serasi antara pusat dan daerah serta antar daerah. Hal tersebut sesuai dengan ketentuan umum di Undang-Undang Otonomi Daerah Nomor 32 Tahun 2004 tentang Pemerintah Daerah yang telah menggantikan Undang-Undang Nomor 22 Tahun 1999. Serta Undang-Undang Nomor 33 Tahun
On Assets.

2004 tentang Perimbangan Keuangan antara Pemerintah Pusat dan Pemerintah Daerah yang telah menggantikan Undang-Undang Nomor 25 Tahun 1999.

Kebijakan otonomi daerah merupakan pendelegasian kewenangan yang disertai dengan penyerahan dan pengalihan pendanaan, sarana dan prasarana dan Sumber Daya Manusia dalam kerangka desentralisasi fiskal. Dalam menghadapi desentralisasi fiskal menunjukan bahwa potensi fiskal pemerintah daerah satu dengan daerah yang lain bisa jadi sangat beragam. Perbedaan ini pada gilirannya dapat menghasilkan pertumbuhan ekonomi yang beragam pula.

Konsekuensi akibat penyerahan kewenangan pemerintah pusat kepada pemerintah daerah mengakibatkan perlunya perimbangan keuangan antara pemerintah pusat dan daerah yang menyebabkan terjadinya transfer yang cukup signifikan di dalam Anggaran Pendapatan dan Belanja Negara dari pemerintah pusat ke pemerintah daerah, dan pemerintah daerah secara leluasa dapat menggunakan dana tersebut untuk memberi pelayanan yang lebih baik kepada masyarakat atau untuk keperluan lain yang 
mungkin tidak penting. Dengan adanya transfer dana dari pusat ini diharapkan pemerintah daerah bisa lebih mengalokasikan pendapatan asli daerah yang didapatnya untuk membiayai belanja daerahnya.

Sementara itu, transfer dana antarpemerintahan merupakan hal yang wajar dan umum terjadi di semua negara di dunia, terlepas dari sistem pemerintahannya (Fisher, 1996). Transfer tersebut diberikan dengan tujuan untuk menginternalisasikan eksternalitas fiskal yang muncul lintas daerah, memperbaiki sistem perpajakan, mengoreksi ketidakseimbangan fiskal, dan mengakomodasi pemerataan fiskal antardaerah (Oates, 1999). Dalam konteks pelaksanaan desentralisasi fiskal di Indonesia, bentuk transfer ke daerah tersebut diberikan dalam bentuk Dana Perimbangan (terdiri dari Dana Alokasi Umum (DAU), Dana Alokasi Khusus (DAK), dan Dana Bagi Hasil (DBH), Dana Otonomi Khusus dan Penyesuaian.

Undang-undang Nomor 33 Tahun 2004 menjelaskan bahwa pemerintah pusat akan mentransfer Dana Perimbangan yang terdiri dari Dana Alokasi Umum (DAU), Dana Alokasi Khusus (DAK), dan bagian daerah dari Dana Bagi Hasil (DBH) yang terdiri dari pajak dan sumber daya alam. Disamping dana perimbangan tersebut, pemerintah daerah mempunyai sumber pendanaan sendiri berupa Pendapatan Asli Daerah (PAD), Pembiayaan, dan lain-lain Pendapatan Asli Daerah yang sah. Kebijakan penggunaan semua dana tersebut diserahkan kepada pemerintah daerah. Dana transfer dari pemerintah pusat maupun pemerintah provinsi diharapkan dapat dipergunakan secara efektif dan efisien oleh pemerintah daerah dalam rangka peningkatan pelayanan kepada masyarakat. Kebijakan yang ditetapkan oleh pemerintah daerah dalam penggunaan dana tersebut sudah seharusnya dilakukan secara transparan dan akuntabel.

Belanja daerah dipergunakan dalam rangka pelaksanaan urusan pemerintahan yang menjadi kewenangan propinsi atau kabupaten/kota yang terdiri dari urusan wajib dan urusan pilihan yang ditetapkan dengan ketentuan perundang-undangan. Belanja penyelenggraan urusan wajib diprioritaskan untuk melindungi masyarakat dalam upaya memenuhi kewajiban daerah yang diwujudkan dalam bentuk peningkatan pelayanan dasar seperti pendidikan, kesehatan, fasilitas sosial dan fasilitas umum yang layak serta mengembangkan sistem jaminan sosial (Peraturan Pemerintah Nomor 58 Tahun 2005).
Menurut Undang-Undang Nomor 33 tahun 2004 tentang Perimbangan Keuangan antara Pemerintah Pusat dan Pemerintah Daerah, menyatakan bahwa Belanja daerah adalah semua kewajiban Daerah yang diakui sebagai pengurang nilai kekayaan bersih dalam periode tahun anggaran yang bersangkutan.

Berkembang dengan pesatnya pembangunan daerah yang menyangkut perkembangan secara fiskal membutuhkan alokasi dana dari pemerintah daerah mengakibatkan pembiayaan pada pos belanja yang terdiri dari pengeluaran rutin dan pengeluaran pembangunan membutuhkan tersedianya dana yang besar pula untuk membiayai kegiatan tersebut. Belanja (pengeluaran) pemerintah daerah yang oleh pemerintah daerah dilaporkan dalam Anggaran Pendapatan dan Belanja Daerah merupakan kegiatan rutin pengeluaran kas daerah untuk membiayai kegiatan-kegiatan operasi dalam pemerintahan.

Selama ini manajemen keuangan daerah masih memprihatinkan. Anggaran daerah, khususnya belanja daerah belum mampu berperan sebagai insentif dalam mendorong laju pembangunan didaerah. Disisi lain banyak ditemukan pengalokasian anggaran yang tidak sesuai dengan kebutuhan dan penggunaannya tidak dilakukan secara hati-hati, sehingga kurang mencerminkan aspek ekonomi, efesiensi dan efektifitas. Hal ini disebabkan kualitas perencanaan anggaran daerah relatif lemah. Perencanaan anggaran yang lemah juga diikuti dengan ketidakmampuan pemerintah daerah untuk meningkatkan penerimaan daerah secara kesinambungan. Sudah merupakan suatu keharusan diera otonomi ini pengelolaan keuangan daerah yang transparan dan akuntabel, sehingga akan meningkatkan kinerja bagi pemerintah daerah.

Menurut Harefa, dkk (2017) mengemukakan bahwa fenomena umum yang dihadapi oleh sebagian besar pemerintahan daerah di Indonesia dari sisi keuangan daerah adalah relatif kecilnya peranan (kontribusi) Pendapatan Asli Daerah di dalam struktur Anggaran Pendapatan dan Belanja Daerah (APBD). Dengan kata lain peranan/ kotribusi penerimaan yang berasal dari dana transfer masih mendominasi susunan Anggaran Pendapatan dan Belanja Daerah. Begitu pula dengan yang terjadi dengan struktur Anggaran Pendapatan dan Belanja Daerah Kota Jayapura, dimana penerimaan dana transfer masih lebih dominan. Lebih jelasnya mengenai hal tersebut dapat dilihat pada tabel berikut ini.

Tabel 1.1

Realisasi Penerimaan PAD dan Dana Transfer Kota Jayapura Tahun 2015-2019

\begin{tabular}{|c|c|c|c|}
\hline Tahun & $\begin{array}{c}\text { Pendapatan Asli Daerah } \\
(\mathrm{Rp})\end{array}$ & $\begin{array}{c}\text { Dana Transfer } \\
(\mathrm{Rp})\end{array}$ & $\begin{array}{c}\text { Belanja Daerah } \\
(\mathrm{Rp})\end{array}$ \\
\hline 2015 & $152.631 .134 .983,34$ & 1.057 .646 .294 .612 & 1.204 .819 .811 .826 \\
\hline 2016 & $164.831 .615 .677,74$ & 1.113 .882 .688 .957 & 1.280 .379 .079 .575 \\
\hline 2017 & $176.666 .250 .172,78$ & 1.046 .127 .433 .209 & 1.187 .042 .622 .291 \\
\hline 2018 & $243.863 .618 .164,31$ & 1.020 .212 .686 .616 & 1.136 .467 .522 .886 \\
\hline 2019 & $235.147 .029 .261,71$ & 1.035 .009 .905 .548 & 1.134 .115 .360 .472 \\
\hline
\end{tabular}

26 Wahab, Pengaruh Pendapatan Asli Daerah, Hal 25 - 41 
Berdasarkan data pada tabel di atas, dapat diketahui bahwa realisasi penerimaan pendapatan asli daerah Kota Jayapura dapat dikatakan masih jauh lebih kecil dibandingkan besarnya pendapatan transfer yang diterima oleh pemerintah daerah Kota Jayapura. Namun demikian, realisasi Pendapatan Asli Daerh Kota Jayapura sejak tahun 2015 sampai 2019 memiliki tren yang cenderung mengalami kenaikan. Realisasi penerimaan dana transfer Kota Jayapura dalam kurun waktu 5 tahun terakhir berfluktuasi dengan nilai yang cukup tinggi dibandingkan realisasi penerimaan pendapatan asli daerah. Sedangkan realisasi belanja daerah Kota Jayapura berdasarkan laporan realisasi anggaran, diketahui bahwa dalam kurun waktu liam tahun terakhir cenderung mengalami penurunan.

Dalam penggunaan semua pendapatan tersebut diserahkan sepenuhnya kepada pemerintah daerah. Namun pemerintah daerah harus menggunakan dana transfer tersebut secara efektif dan efisien dalam rangka peningkatkan standar pelayanan publik minimum serta disajikan secara transparan dan akuntabel. Akan tetapi pada praktiknya, dana transfer seringkali dijadikan sumber dana utama oleh pemerintah daerah untuk membiayai operasi utama sehari-hari, yang oleh pemerintah daerah dilaporkan diperhitungan Anggaran Pendaptan dan Belanja Daerah (APBD).

Berdasarkan latar belakang di atas, maka penulis akan melakukan penelitian dengan judul Pengaruh Pendapatan Asli Daerah Dan Dana Transfer Terhadap Belanja Daerah Kota Jayapura.

\section{Perumusan Masalah}

Adapun masalah yang akan dibahas dalam penelitian ini, berikut penulis rumuskan dalam bentuk pertanyaan sebagai berikut:

1. Apakah pendapatan asli daerah berpengaruh terhadap belanja daerah Kota Jayapura?

2. Apakah dana transfer berpengaruh terhadap belanja daerah Kota Jayapura?

3. Apakah pendapatan asli daerah dan dana transfer secara simultan berpengaruh terhadap belanja daerah Kota Jayapura?

\section{TINJAUAN PUSTAKA}

Kajian Teori

Anggaran Pendapatan dan Belanja Daerah (APBD)

\section{Pengertian dan Unsur-unsur Anggaran} Pendapatan dan Belanja Daerah

Anggaran Pendapatan dan Belanja Daerah (APBD) merupakan suatu rencana keuangan tahunan daerah yang memuat tentang rencana penerimaan, rencana pengeluaran serta rencana pembiayaan daerah selama satu tahun anggaran. Menurut Bastian (2006:189), Anggaran Pendapatan dan Belanja Daerah merupakan pengejawantahan rencana kerja Pemda dalam bentuk satuan uang untuk kurun waktu satu tahunan dan berorientasi pada tujuan kesejahteraan publik. Menurut Saragih (2003:122), Anggaran Pendapatan dan Belanja Daerah (APBD) adalah dasar dari pengelolaan keuangan daerah dalam tahun anggaran tertentu, umumnya satu tahun.

Menurut Mamesah dalam Halim (2007:20), Anggaran Pendapatan dan Belanja Daerah dapat didefenisikan sebagai: Rencana operasional keuangan Pemerintah Daerah, dimana disatu pihak menggambarkan perkiraan pengeluaran setinggitingginya guna membiayai kegiatan-kegiatan dan proyek-proyek daerah dalam satu tahun anggaran tertentu, dan pihak lain menggambarkan perkiraan penerimaan dan sumber-sumber penerimaan daerah guna menutupi pengeluaran-pengeluaran yang dimaksud. Menurut Halim dan Nasir (2006 :44), Anggaran Pendapatan dan Belanja Daerah adalah rencana keuangan tahunan Pemerintah Daerah yang dibahas dan disetujui bersama oleh Pemerintah Daerah dan Dewan Perwakilan Daerah, dan ditetapkan dengan Peraturan Daerah.

Pada era Orde Lama, defenisi Anggaran Pendapatan dan Belanja Daerah yang dikemukakan oleh Wajong (1962:81) dalam Halim (2004:15) adalah: Rencana pekerjaan keuangan (financieel werkplan) yang dibuat untuk jangka waktu tertentu, dalam waktu mana badan legislatif (DPRD) memberikan kredit kepada badan eksekutif (kepala daerah) untuk melakukan pembiayaan guna kebutuhan rumah tangga daerah sesuai dengan rancangan yang menjadi dasar (grondslag) penetapan anggaran, dan yang menunjukkan semua penghasilan untuk menutup pengeluaran tadi.

Unsur-unsur Anggaran Pendapatan dan Belanja Daerah menurut Halim (2004:15-16) adalah sebagai berikut:

a. Rencana kegiatan suatu daerah, beserta uraiannya secara rinci,

b. Adanya sumber penerimaan yang merupakan target minimal untuk menutupi biaya-biaya sehubungan dengan aktivitas tersebut, dan adanya biya-biaya yang merupakan batas maksimal pengeluran-pengeluaran yang akan dilaksanakan,

c. Jenis kegiatan dan proyek yang dituangkan dalam bentuk angka,

d. Periode anggaran yang biasanya 1 (satu) tahun.

2. Struktur Anggaran Pendapatan dan Belanja Daerah

Struktur Anggaran Pendapatan dan Belanja Daerah yang terbaru adalah berdasarkan Peraturan Menteri Dalam Negeri nomor 13 tahun 2006 tentang pedoman pengelolaan keuangan daerah. Adapun bentuk dan susunan Anggaran Pendapatan dan Belanja Daerah yang didasarkan pada Permendagri 13/ 2006 pasal 22 ayat (1) terdiri atas 3 bagian, yaitu:pendapatan daerah, belanja daerah, dan pembiayaan daerah.

Pendapatan daerah sebagaimana dimaksud dalam pasal 22 ayat (1) dikelompokkan atas pendapatan asli daerah, dana perimbangan, dan lainlain pendapatan daerah yang sah. Belanja menurut kelompok belanja terdiri dari belanja tidak langsung dan belanja langsung. Pembiayaan daerah terdiri dari penerimaan pembiayaan dan pengeluaran pembiayaan. 
Penerimaan pembiayaan mencakup sisa lebih perhitungan anggaran tahun anggaran sebelumnya (SiLPA), pencairan dana cadangan, hasil penjualan kekayaan daerah yang dipisahkan, penerimaan pinjaman daerah, penerimaan kembali pemberian pinjaman, dan penerimaan piutang daerah. Pengeluaran pembiayaan mencakup pembentukan dana cadangan, penyertaan modal (investasi) pemerintah daerah, pembayaran pokok utang, dan pemberian pinjaman daerah. (Permendagri 13/ 2006). Sedangkan struktur Anggaran Pendapatan dan Belanja Daerah berdasarkan format Keputusan Menteri Dalam Negeri No. 29 Tahun 2002 terdiri atas 3 bagian, yaitu:pendapatan, belanja, dan pembiayaan.

Pendapatan dibagi menjadi 3 kategori yaitu Pendapatan Asli Daerah (PAD), Dana Perimbangan, dan lain-lain pendapatan daerah yang sah. Belanja digolongkan menjadi 4 yakni belanja aparatur daerah, belanja pelayanan publik, belanja bagi hasil dan bantuan keuangan, dan belanja tak tersangka. Belanja aparatur daerah diklasifikasi menjadi 3 kategori yaitu belanja administrasi umum, belanja operasi dan pemeliharaan, dan belanja modal/ pembangunan. Belanja pelayanan publik dikelompokkan menjadi 3 yakni belanja administrasi umum, belanja operasi dan pemeliharaan, dan belanja modal. Pembiayaan dikelompokkan menurut sumber-sumber pembiayaan yaitu: sumber penerimaan daerah dan sumber pengeluaran daerah. Sumber pembiayaan berupa penerimaan daerah adalah:sisa lebih anggaran tahun lalu, penerimaan pinjaman dan obligasi, hasil penjualan aset daerah yang dipisahkan dan transfer dari dana cadangan. Sumber pembiayaan berupa pengeluaran daerah terdiri atas:pembayaran utang pokok yang telah jatuh tempo, penyertaan modal, transfer ke dana cadangan, dan sisa lebih anggaran tahun sekarang. (Halim, 2004:18).

\section{Konsep Anggaran Pemerintah}

Menurut Permendagri No. 13 tahun 2006 pasal 23, pendapatan daerah meliputi semua penerimaan uang melalui rekening kas umum daerah, yang menambah ekuitas dana, merupakan hak daerah dalam satu tahun anggaran dan tidak perlu dibayar kembali oleh daerah. Pendapatan daerahdapat dikelompokkan antara lain sebagai berikut.

1) Pendapatan Asli Daerah (PAD) terdiri dari sebagai berikut ini.

a. Pajak daerah,

b. Retribusi daerah,

c. Hasil pengelolaan kekayaan daerah yang dipisahkan yang mencakup sebagai berikut.

a) Bagian laba atas penyertaan modal pada perusahaanmilik daerah/Badan Usaha Milik Daerah,

b) Bagian laba atas penyertaan modal pada perusahaan milik pemerintah / Badan Usaha Milik Negara, c) Bagian laba atas penyertaan modal pada perusahaan milik swasta atau kelompok usaha masyarakat.

d. Lain-lain pendapatan asli daerah yang sah, disediakan untuk menganggarkan penerimaan daerah yang tidak termasuk dalam jenis pajak daerah, retribusi daerah, dan hasil pengelolaan kekayaan daerah yang dipisahkan. Lain-lain pendapatan asli daerah yang sah dirinci menurut objek pendapatan yang mencakup:

a) Hasil penjualan kekayaan daerah yang tidak dipisahkan,

b) Jasa giro,

c) Pendapatan bunga,

d) Penerimaan atas tuntutan ganti kerugian daerah,

e) Penerimaan komisi, potongan ataupun bentuk lain sebagai akibat dari penjualan dan/atau pengadaan barang dan/atau jasa oleh daerah,

f) Penerimaan keuntungan dari selisih nilai tukar rupiah terhadap mata uang asing,

g) Pendapatan denda atas keterlambatan pelaksanaan pekerjaan,

h) Pendapatan denda pajak,

i) Pendapatan denda retribusi,

j) Pendapatan hasil eksekusi atas jaminan.

2) Dana Perimbangan

Menurut Permendagri No. 13 tahun 2006 pasal 27, dana perimbangan dibagi menjadi.

a. Dana Bagi Hasil (DBH), terdiri dari sebagai berikut.
a) Bagi hasil pajak, dan
b) Bagi hasil bukan pajak.

b. Dana Alokasi Umum (DAU), dan

c. Dana Alokasi Khusus (DAK)

3) Lain-lain pendapatan daerah yang mencakup.

a. Hibah, yaitu penerimaan daerah yang berasal dari pemerintah negara asing, badan/lembaga asing, badan/ lembaga internasional, pemerintah, badan/ lembaga dalam negeri atau perorangan, balk dalam bentuk devisa, rupiah maupun barang dan/atau jasa, termasuk tenaga ahli dan pelatihan yang tidak perlu dibayar kembali,

b. Dana darurat dari pemerintah dalam rangka penanggulangan korban/kerusakan akibat bencana alam,

c. Dana bagi hasil pajak dari provinsi kepada kabupaten/kota,

d. Dana penyesuaian dan dana otonomi khusus yang ditetapkan oleh pemerintah, dan

e. Bantuan keuangan dari provinsi atau dari pemerintah daerah lainnya.

Pada akhirnya pemerintah akan melakukan transfer dana. Transfer dana ini berupa dana perimbangan. Dana perimbangan adalah pengeluaran alokasi anggaran pemerintah pusat untuk pemerintah daerah yang ditujukan untukkeperluan pemerintah daerah 
(www.ksap.org). Kuncoro (2007) juga menyebutkan bahwa PAD hanya mampu membiayai belanja pemerintah daerah paling tinggi sebesar 20\%. Kemandirian bagi daerah belum sepenuhnya terlaksana, karena mereka masih menggantungkan dengan adanya aliran dana dari pemerintah pusat, khususnya Dana Alokasi Umum. Dana Perimbangan ini terdapat berbagai macam, yaitu DAU (Dana Alokasi Umum), DAK (Dana Alokasi Khusus), dan DBH (Dana BagiHasil). Dana perimbangan tersebut diperuntukkan untuk: (i) menjamin terciptanyaperimbangan secara vertikal di bidang keuangan antar tingkat pemerintahan; (ii) menjamin terciptanya perimbangan horizontal di bidang keuangan antarpemerintah di tingkat yang sama; (iii) dan menjamin terselenggaranya kegiatan kegiatan tertentu di daerah yang sejalan dengan kepentingan nasional. Dana yang biasanya ditransfer dari pemerintah pusat adalah dana alokasi umum. Pada kenyataannya proporsi Dana Alokasi Umum terhadap penerimaan daerah masih yang tertinggi dibandingkan dengan penerimaan daerah yang lain, termasuk pendapatan asli daerah.

Berkaitan dengan hal itu, strategi alokasi belanja daerah memainkan peranan yang tidak kalah penting guna meningkatkan penerimaan daerah. Dalam upaya untuk meningkatkan kontribusi publik terhadap penerimaan daerah, alokasi belanja modal hendaknya lebih ditingkatkan. Belanja Modal yang dilakukan oleh pemerintah daerah diantaranya pembangunan dan perbaikan sektor pendidikan, kesehatan, transportasi, sehingga masyarakat juga menikmati manfaat dari pembangunan daerah. Oleh karena itu, anggaran belanja daerah akan tidak logisjika proporsi anggarannya lebih banyak untuk belanja rutin (Abimanyu, 2005). Semakin banyak pendapatan yang dihasilkan oleh daerah, baik dari Dana Alokasi Umum maupun pendapatan asli daerah sendiri, daerah akan mampu memenuhi dan membiayai semua keperluan yang diharapkan oleh masyarakat.

\section{Pendapatan Asli Daerah}

Menurut Undang-Undang No. 25 tahun 1999, pendapatan asli daerah merupakan semua penerimaan daerah yang berasal dari potensi sumber daya yang ada di daerah. Sumber-sumber pendapatan asli daerah meliputi hasil pajak daerah, hasil retribusi daerah, hasil perusahaan milik daerah dan hasil pengelolaan kekayaan daerah lainnya yang dipisahkan, lain-lain pendapatan asli daerah yang sah. Pendapatan asli daerah adalah pendapatan yang diperoleh dari sumbersumber pendapatan daerah dan dikelola sendiri oleh pemerintah daerah. Pendapatan asli daerah merupakan tulang punggung pembiayaan daerah, oleh karenanya kemampuan melaksanakan ekonomi diukur dari besarnya kontribusi yang diberikan oleh Pendapatan Asli Daerah terhadap Anggaran Pendapatan dan Belanja Daerah, semakin besar kontribusi yang dapat diberikan oleh Pendapatan Asli Daerah terhadap Anggaran Pendapatan dan Belanja Daerah berarti semakin kecil ketergantungan Pemerintah daerah terhadap bantuan Pemerintah pusat.

Menurut Undang-Undang No. 33 Tahun 2004 pasal 1, Pendapatan Asli Daerah adalah penerimaan yang diperoleh daerah dari sumber-sumber di dalam daerahnya sendiri yang dipungut berdasarkan peraturan daerah sesuai dengan peraturan perundangundangan yang berlaku. Pendapatan Asli Daerah merupakan sumber penerimaan daerah yang asli digali di daerah yang digunakan untuk modal dasar Pemerintah daerah dalam membiayai pembangunan dan usaha-usaha daerah untuk memperkecil ketergantungan dana dari pemerintah pusat.

Menurut Undang-Undang No. 33 Tahun 2004 pasal 6, Sumber-sumber Pendapatan Asli Daerah terdiri dari: a. Pajak Daerah, b. Retribusi daerah. c. Hasil pengelolaan kekayaan daerah yang dipisahkan, d. Lain-lain Pendapatan Asli Daerah (PAD) yang sah. Menurut Mardiasmo (2002:132), Pendapatan Asli Daerah adalah penerimaan daerah dari sektor pajak daerah, retribusi daerah, hasil perusahaan milik daerah, hasil pengelolaan kekayaan daerah yang dipisahkan, dan lain-lain Pendapatan Asli Daerah yang sah. Menurut Halim (2004:67) Pendapatan Asli Daerah (PAD) merupakan semua penerimaan daerah yang berasal dari sumber ekonomi asli daerah. Pendapatan Asli Daerah dipisahkan menjadi empat jenis pendapatan, yaitu:pajak daerah, retribusi daerah, hasil perusahaan milik daerah dan hasil pengelolaan kekayaan milik daerah yang dipisahkan, lain-lain PAD yang sah.

\section{Intergovernmental Revenue}

Intergovernmental Revenue adalah sejumlah transfer dana dari pusat yang sengaja dibuat untuk membiayai program-program pemerintah daerah (Nam, 2001). Dengan desentralisasi fiskal terjadi aliran dana yang cukup besar dari pemerintah pusat ke pemerintah daerah (Syahrudin, 2006). Pemerintah daerah dituntut untuk meningkatkan akuntabilitas pengelolaan dan pelaporan keuangan pemerintahnya. Idealnya desentralisasi fiskal dapat meningkatkan efisiensi, efektifitas, transparansi dan akuntabilitas pengelolaan keuangan pemerintah.

Kondisi ini terbukti pada beberapa daerah dimana desentralisasi fiskal meningkatkan pertumbuhan ekonomi, meningkatkan partisipasi masyarakat dalam pengambilan keputusan dan meningkatkan kualitas pelayanan publik. Menurut Peraturan Menteri Dalam Negeri No.32 Tahun 2008 (Permendagri No.32/2008), dalam rangka pelaksanaan desentralisasi, kepada daerah diberikan Dana Perimbangan melalui Anggaran Pendapatan dan Belanja Negara yang bersifat transfer dengan prinsip money follows function. Salah satu tujuan pemberian Dana Perimbangan tersebut adalah untuk mengurangi kesenjangan fiskal antara pemerintah dengan daerah dan antar daerah, serta meningkatkan kapasitas daerah dalam menggali potensi ekonomi. 
Menurut Undang-Undang No. 33 Tahun 2004 tentang perimbangan antara pemerintah pusat dan daerah, yang dimaksud dengan dana alokasi umum yaitu dana yang berasal dari Anggaran Pendapatan dan Belanja Negara yang dialokasikan dengan tujuan pemerataan kemampuan keuangan antar daerah membiayai kebutuhan pengeluarannya dalam rangka pelaksanaan desentralisasi. Pada Pasal 7 UndangUndang No.33 Tahun 2004, besarnya Dana Alokasi Umum ditetapkan sekurang-kurangnya 25 persen dari penerimaan dalam negeri yang ditetapkan dalam Anggaran Pendapatan dan Belanja Negara. Dana Alokasi Umum untuk daerah Propinsi dan untuk daerah kabupaten/kota ditetapkan masing-masing 10 persen dan 90 persen dari Dana Alokasi Umum. Dana Alokasi umum merupakan salah satu dari dana perimbangan. Menurut pasal 1 Undang-Undang No.33 Tahun 2004, Dana Alokasi Umum, selanjutnya disebut Dana Alokasi Umum adalah dana yang bersumber dari pendapatan Anggaran Pendapatan dan Belanja Negara yang dialokasikan dengan tujuan pemerataan kemampuan keuangan antar daerah untuk mendanai kebutuhan daerah dalam rangka pelaksanaan desentralisasi.

\section{Dana Perimbangan}

Menurut Djaenuri (2012:100), pengertian mengenai dana perimbangan merupakan sumber pendapatan daerah yang berasal dari Anggaran Pendapatan dan Belanja Negara untuk mendukung pelaksanaan kewenanangan pemerintah daerah dalam mencapai tujuan pemberian otonomi kepada daerah, terutama peningkatan pelayanan dan kesejahteraan masyarakat yang semakin baik. Dengan demikian, sejalan dengan tujuan pokoknya, dana perimbangan dapat lebih memperdayakan dan meningkatkan kemampuan perekonomian daerah, menciptakan sistem pembayaran yang adil, proporsional, rasioanl, transparan partisipatif, bertanggungjawab (akuntabel), serta memberikan kepastian sumber keuangan daerah yang berasal dari wilayah daerah yang bersangkutan.

Sedangkan menurut Undang-Undang No. 33 tahun 2004 tentang Perimbangan Keuangan Antara Pemerintah Pusat dan Pemerintah, "Dana Perimbangan adalah dana yang bersumber dari pendapatan Anggaran Pendapatan dan Belanja Negara yang dialokasikan kepada daerah untuk mendanai kebutuhan Daerah dalam rangka pelaksanaan Desentralisasi”. Dana perimbangan memiliki tujuan untuk mengurangi kesenjangan fiscal antar pemerintah daerah. Dana perimbangan terdiri dari Dana Alokasi Umum (DAU), Dana Alokasi Khusus (DAK), dan Dana Bagi Hasil (DBH).

\section{1) Dana Alokasi Umum}

Menurut Undang-Undang Nomor 33 Tahun 2004 tentang Perimbangan Keuangan Pusat dan Keuangan Daerah disebutkan bahwa Dana Alokasi Umum adalah dana yang bersumber dari pendapatan Anggaran Pendapatan dan Belanja Negara yang dialokasikan dengan tujuan pemerataan kemampuan keuangan antar daerah untuk mendanai kebutuhan daerah dalam pelaksanaan desentralisasi. Menurut Awaniz (2011: 19) Dana alokasi umum merupakan jenis transfer dana antar tingkat pemerintahan yang tidak terikat dengan program pengeluaran tertentu. Sedangkan menurut Halim (2016: 127) menjelaskan bahwa Dana alokasi umum adalah transfer dana yang bersifat block grant, sehingga pemerintah daerah mempunyai keleluasaan di dalam penggunaan Dana Alokasi Umum sesuai dengan kebutuhan dan aspirasi masing-masing daerah.

Berdasarkan Pasal 1 ayat 21 UndangUndang No. 33 Tahun 2004, Dana Alokasi Umum adalah dana yang bersumber dari pendapatan Anggaran Pendapatan dan Belanja Negara yang dialokasikan dengan tujuan pemerataan kemampuan keuangan antar daerah untuk mendalami kebutuhan daerah dalam rangka pelaksanaan desentralisasi. Kata "umum" dalam Dana Alokasi Umum mengandung pengertian bahwa Dana Alokasi Umum merupakan block grant yang artinya kewenangan pengaturan penggunaannya diserahkan sepenuhnya kepada daerah sesuai dengan tujuan pemberiaan otonomi daerah. Mardiasmo (2007:157) menyatakan bahwa tujuan alokasi Dana Alokasi Umum terutama adalah untuk horizontal equity dan sufficiency. Tujuan horizontal equity merupakan kepentingan pemerintah pusat dalam rangka melakukan distribusi pendapatan secara adil dan merata agar tidak terjadi kesenjangan antar daerah. Sementara itu, yang menjadi kepentingan daerah adalah kecukupan (sufficiency), terutama untuk menutupi fiscal gap. Dana Alokasi Umum mempunyai bagian-bagian, yaitu:

a. Dana Alokasi Umum untuk Daerah Provinsi

Dana Alokasi Umum ditetapkan minimal 26\% dari Pendapatan Dalam Negeri (PDN) Netto yang ditetapkan dalam Anggaran Pendapatan dan Belanja Negara, $10 \%$ untuk Dana Alokasi Umum daerah provinsi.

\section{b. Dana Alokasi Umum untuk Daerah Kabupaten/ Kota}

Dana Alokasi Umum ditetapkan minimal 26\% dari Pendapatan Dalam Negeri (PDN) Netto yang ditetapkan dalam Anggaran Pendapatan dan Belanja Negara, 90 \% untuk Dana Alokasi Umum daerah kabupaten/ kota.

Apabila Dana Alokasi Umum (DAU)
yang diterima oleh daerah lebih besar
dibandingkan dengan Pendapatan Asli Daerah
(PAD) yang dihasilkan daerah tersebut maka hal
tersebut berarti tingkat kemandirian keuangan
daerah tersebut masih rendah atau dapat dikatakan
bahwa daerah tersebut belum mandiri sebab masih
bergantung pada Dana Alokasi Umum dari
pemerintah pusat. Indraningrum (2011: 23) mengidentifikasi beberapa tujuan pemerintah pusat memberikan 
dana bantuan dalam bentuk Dana Alokasi Umum (block grant) kepada pemerintah daerah, yaitu:

a.Untuk mendorong terciptanya keadilan antar wilayah (geographical equity);

b. Untuk meningkatkan akuntabilitas (promote accountability);

c.Untuk meningkatkan sistem pajak yang lebih progresif. Pajak daerah cenderung kurang progresif, membebani tarif pajak yang tinggi kepada masyarakat yang berpenghasilan rendah;

d. Untuk meningkatkan keberterimaan (acceptability) pajak daerah. Pemerintah pusat mensubsidi beberapa pengeluaran pemerintah daerah untuk mengurangi jumlah pajak daerah.

Sedangkan menurut Halim (2016:127) menjelaskan bahwa tujuan dibentuknya Dana Alokasi Umum adalah yaitu Dana Alokasi Umum mengurangi ketimpangan dalam kebutuhan pembiayaan daerah, Dana Alokasi Umum akan memberikan kepastian bagi daerah untuk membiayai kebutuhan pengeluaran yang menjadi tanggung jawab masing-masing daerah dengan proporsi sekurang-kurangnya $26 \%$ dari pendapatan dalam negeri netto yang telah ditetapkan dalam Anggaran Pendapatan dan Belanja Negara.

Ketimpangan ekonomi antara satu provinsi dengan provinsi lain tidak dapat dihindari dengan adanya desentralisasi fiskal. Disebabkan oleh minimnya sumber pajak dan sumber daya alam yang kurang dapat digali oleh Pemerintah daerah. Untuk menanggulangi ketimpangan tersebut, Pemerintah pusat berinisiatif untuk memberikan subsidi berupa Dana Alokasi Umum kepada daerah. Bagi daerah yang tingkat kemiskinannya lebih tinggi, akan diberikan Dana Alokasi Umum lebih besar dibanding daerah yang kaya dan begitu juga sebaliknya.

\section{2) Dana Alokasi Khusus}

Menurut Halim (2014:16) "Dana Alokasi Khusus (DAK) adalah dana yang bersumber dari Anggaran Pendapatan dan Belanja Negara yang dialokasikan kepada daerah tertentu dengan tujuan untuk membantu mendanai kegiatan khusus yang merupakan urusan daerah dan sesuai dengan prioritas nasional".

Definisi Dana Alokasi Khusus (DAK) Menurut Peraturan Pemerintah No. 55/ 2005 yaitu: Dana Alokasi Khusus (DAK) adalah dana yang bersumber dari pendapatan Anggaran Pendapatan dan Belanja Negara yang dialokasikan kepada daerah tertentu yang mempunyai kebutuhan khusus dengan tujuan untuk membantu mendanai kegiatan khusus yang merupakan urusan daerah sesuai dengan prioritas nasional. Pembiayaan kebutuhan khusus memerlukan dana pendamping dari penerimaan umum Anggaran Pendapatan dan Belanja Daerah sekurang-kurangnya $10 \%$ (sepuluh persen) sebagai komitmen dan tanggung jawab daerah dalam pembiayaan program- program yang merupakan kebutuhan khusus tersebut. Dana Alokasi Khusus dimaksudkan untuk membantu daerah dalam mendanai kebutuhan sarana dan prasarana pelayanan masyarakat seperti pelayanan pendidikan, kesehatan dan infrastruktur masyarakat dalam rangka mendorong percepatan pembangunan daerah dan pencapaian sasaran prioritas nasional".

Dana Alokasi Khusus (DAK) menurut Undang-Undang Nomor 33 Tahun 2004 yaitu: Dana Alokasi Khusus (DAK) adalah dana yang berasal dari Anggaran Pendapatan dan Belanja Negara yang dialokasikan kepada daerah untuk membantu membiayai kebutuhan tertentu. Dana Alokasi Khusus dipergunakan untuk menutupi kesenjangan pelayanan publik antar daerah dengan memberikan prioritas pada bidang pendidikan, kesehatan, infrastruktur, kelautan dan perikanan, pertanian, prasarana pemerintah daerah, serta lingkungan hidup.

Darise (2008) mengemukakan bahwa Dana Alokasi Khusus (DAK) bertujuan untuk: Tujuan Dana Alokasi Khusus (DAK) adalah untuk membantu membiayai kegiatan-kegiatan khusus di daerah tertentu yang merupakan urusan daerah dan sesuai dengan prioritas nasional, khususnya untuk membiayai kebutuhan sarana dan prasarana pelayanan dasar masyarakat yang belum mencapai standar tertentu atau untuk mendorong percepatan pembangunan daerah. Pemerintah menetapkan kriteria Dana Alokasi Khusus yang meliputi kriteria umum, kriteria khusus, dan kriteria teknis. Kriteria umum ditetapkan dengan mempertimbangkan kemampuan Keuangan Daerah dalam Anggaran Pendapatan dan Belanja Daerah. Kriteria khusus ditetapkan dengan memperhatikan peraturan perundang-undangan dan karakteristik Daerah. Kriteria teknis ditetapkan oleh kementerian Negara/ departemen teknis",

Dana Alokasi Khusus (DAK) menurut Bahar (2009: 156) yaitu: Dana Alokasi Khusus (DAK) adalah dana yang bersumber dari Anggaran Pendapatan dan Belanja Negara yang dialokasikan kepada daerah tertentu dengan tujuan untuk mendanai kegiatan khusus yang merupakan urusan daerah dan sesuai dengan prioritas nasional, khususnya untuk membiayai kebutuhan sarana dan prasarana pelayanan dasar masyarakat yang masih belum mencapai standar tertentu atau untuk mendorong percepatan pembangunan daerah. Yang dimaksung daerah tertentu adalah alokasi Dana Alokasi Khusus. Dengan demikian tidak semua daerah mendapatkannya. Pemerintah menetapkan tiga kriteria bagi suatu daerah agar mendapatkan Dana Alokasi Khusus, yaitu kriteria umum, kriteria khusus, dan kriteria teknis".

Pelaksanaan Dana Alokasi Khusus sendiri diarahkan pada kegiatan investasi pembangunan, pengadaan, peningkatan, dan/ atau perbaikan sarana dan prasarana fisik pelayanan masyarakat dengan umur ekonomis yang panjang, termasuk pengadaan sarana 
fisik penunjang, dan tidak termasuk penyertaan modal. Sebagai contoh, penggunaan Dana Alokasi Khusus bidang pendidikan meliputi:

a. Rehabilitasi gedung sekolah/ ruang kelas,

b. Pengadaan/ rehabilitasi sumber dan sanitasi air bersih serta kamar mandi dan WC,

c. Pengadaan/ perbaikan meubelair ruang kelas dan lemari perpustakaan,

d. Pembangunan/ rehabilitasi rumah dinas penjaga/ guru/ kepala sekolah, dan

e. Peningkatan mutu sekolah dengan pembangunan/ penyediaan sarana dan prasarana perpustakaan serta fasilitas pendidikan lainnya di sekolah.

Kebijakan Dana Alokasi Khusus dapat dibagi menjadi 4 kelompok besar yaitu (i) penetapan program dan kegiatan, (ii) penghitungan alokasi Dana Alokasi Khusus, (iii) arah kegiatan dan penggunaan Dana Alokasi Khusus, dan (iv) administrasi pengelolaan Dana Alokasi Khusus.

3) Dana Bagi Hasil

Berdasarkan Undang-Undang No. 33 Tahun 2004, Dana Bagi Hasil adalah dana yang diperoleh dari Penerimaan Pajak Bumi dan Bangunan, Bea Perolehan Hak atas Tanah dan Bangunan, dan Penerimaan dari Sumber Daya Alam (SDA). Dana Bagi Hasil (DBH) merupakan komponen dana perimbangan yang memiliki peranan penting dalam menyelenggarakan otonomi daerah karena penerimaannya didasarkan atas potensi daerah penghasil sumber pendapatan daerah yang cukup potensial. Melalui bagi hasil penerimaan tersebut, diharapkan potensi penerimaan daerah menjadi semakin meningkat dan daerah merasa bahwa haknya atas pemanfaatan sumber daya alam yang dimiliki masing-masing daerah diperhatikan oleh pemerintah pusat. Dengan sistem pembagian yang didasarkan atas daerah asal (by origin), sebagian penerimaan yang diperoleh dari daerah penghasil harus diberikan dan dinikmati oleh daerah penghasil yang bersangkutan.

Dana Bagi Hasil (DBH) adalah dana yang bersumber dari pendapatan Anggaran Pendapatan dan Belanja Negara yang dialokasikan kepada daerah berdasarkan angka persentase untuk mendanai kebutuhan daerah dalam rangka pelakasanaan desentralisasi (Undang-Undang No. 33 Tahun 2004). Dana bagi hasil yang ditransfer pemerintah pusat kepada pemerintah daerah terdiri dari (2) dua jenis, yaitu dana bagi hasil pajak dan dana bagi hasil sumber daya alam. Pola bagi hasil penerimaan tersebut dilakukan dengan persentase tertentu yang didasarkan atas daerah penghasil.

a. Dana Bagi Hasil Pajak

Dana bagi hasil berasal dari pajak adalah bagian daerah yang berasal dari penerimaan Pajak bumi dan Bangunan, Biaya perolehan Hak Atas Tanah dan Bangunan, Pajak Penghasilan Pasal 25 dan Pasal 29 Wajib Pajak Orang pribadi Dalam Negeri dan
Pajak Penghasilan Pasal 21. Penetapan alokasi Pajak ditetapkan oleh Menteri Keuangan. Dana bahi hasil pajak disalurkan dengan cara pemindah bukuan dari Rekening Kas Umum Negara ke Rekening Kas Umum Daerah.

b. Dana Bagi Hasil Pajak Bumi dan Bangunan

Penerimaan negara dari Pajak Bumi dan Bangunan dibagi dengan imbangan $10 \%$ untuk pemerintahan dan $90 \%$ untuk daerah. Dana bagi hasil Pajak Bumi dan Bangunan untuk daerah sebesar $90 \%$ untuk sebagaimana dimaksud di atas dibagi dengan rincian sebagai berikut:

a. $16,2 \%$ untuk daerah propinsi yang
bersangkutan
b. $64,8 \%$ untuk kabupaten/ kota yang
bersangkutan
c. $9 \%$ untuk biaya pemungutan
Selanjutanya 10 persen penerimaan Pajak Bumi dan Bangunan bagian pemerintah pusat sebagaimana pembagian diatas dialokasikan kepada seluruh kabupaten dan kota. Alokasi untuk kabupaten dan kota sebesar $10 \%$ bagian pemerintah pusat di atas dibagi dengan rincian sebagai berikut:

a) $6,5 \%$ dibagikan secara merata kepada seluruh kabupaten dan kota. Pembagian ini dimaksudkan dalam rangka pemerataan kemampuan keuangan daerah.

b) 3,5\% dibagikan sebagai insentif kepada kabupaten/ kota yang realisasi penerimaan Pajak Bumi dan Bangunan sektor pedesaan dan perkotaan pada tahun anggaran sebelumnya mencapai/ melampaui rencana penerimaan yang ditetapkan. Pemberian insentif ini dimaksudkan untuk mendorong intensifikasi pemungutan Pajak Bumi dan Bangunan.

c. Dana Bagi Hasil Biaya perolehan hak Atas Tanah dan Bangunan

Penerimaan negara-negara dari Biaya perolehan hak Atas Tanah dan Bangunan dibagi dengan imbangan 20\%, untuk pemerintah dan $80 \%$ untuk daerah. Dana Bagi Hasil Biaya perolehan hak Atas Tanah dan Bangunan untuk daerah sebesar $80 \%$ (delapan puluh persen) dibagi dengan rincian sebagai berikut: $16 \%$ (enam belas persen) untuk provinsi yang bersangkutan; dan $64 \%$ (enam puluh empat persen) untuk kabupaten/ kota yang bersangkutan. Bagian pemerintah sebesar 20\% (dua puluh persen) dialokasikan dengan porsi yang sama besar untuk seluruh kabupaten dan kota. Alokasi dana bagi hasil Pajak Bumi dan Bangunan ditetapkan berdasarkan rencana penerimaan Pajak Bumi dan Bangunan dan Biaya perolehan hak Atas Tanah dan Bangunan tahun anggaran bersangkutan, dan paling lambat 2 bulan 
sebelum tahun anggaran bersangkutan dilaksanakan.

d. Pajak Penghasilan Pasal 25 dan Pasal 29 Wajib Pajak Orang pribadi Dalam Negeri dan Pajak Penghasilan Pasal 21.

Pajak penghasilan pasal 25 adalah pembayaran pajak penghasilan secara angsuran. Tujuannya adalah untuk meringankan beban wajib pajak, mengingat pajak yang terutang harus dilunasi dalam waktu satu tahun. Pembayaran ini harus dilakukan sendiri dan tidak bisa diwakilkan. Sedangkan pajak penghasilan pasal 29 adalah pajak penghasilan kurang bayar yang telah tercantum dalam SPT Tahunan pajak penghasilan, yakni sisa dari pajak penghsilan yang terutang dalam tahun pajak yang bersangkutan dikurangi dengan kredit pajak penghasilan dan juga pajak penghasilan pasal 25. Kemudian pajak penghasilan pasal 21 ialah pajak atas penghasilan berupa gaji, upah, honorarium, tunjangan dan pembayaran lain dengan nama dan dalam bentuk apa pun sehubungan dengan pekerjaan atau jabatan, jasa, dan kegiatan yang dilakukan oleh orang pribadi subjek pajak dalam negeri.

e. Dana Bagi Hasil Sumber Daya Alam

Dana Bagi Hasil Sumber Daya Alam berasal dari Kehutanan, Pertambangan umum, Perikanan, Pertambangan Minyak Bumi, Pertambangan Gas Bumi dan Pertambangan Panas Bumi.

a. Sumber Daya Alam Kehutanan

Dana bagi hasil sumber alam kehutanan berasal dari Iuran Izin Usaha Pemanfaatan Hutan (IIUPH), Provinsi Sumber Daya Hutan (PSDH) dan Dana Reboisasi (DR). Dana Bagi Hasil Kehutanan yang berasal dari Iuran Izin Usaha Pemanfaatan Hutan untuk daerah adalah sebesar $80 \%$ dengan rincian, $16 \%$ untuk provinsi yang bersangkutan dan $64 \%$ untuk kabupaten/ kota penghasil. Dana Bagi Hasil Kehutanan yang berasal dari Provisi Sumber Daya Hutan untuk daerah adalah sebesar $80 \%$ dengan rincian $16 \%$ untuk provinsi yang bersangkutan, 32\% untuk kabupaten/ kota penghasil dan 32\% untuk kabupaten/ kota lainnya dalam provinsi yang bersangkutan. Dana Bagi Hasil Kehutanan yang berasal dari Provisi Sumber Daya Hutan dibagikan dengan porsi yang sama besar untuk seluruh kabupaten/ kota lainnya dalam provinsi yang bersangkutan. Dana Bagi Hasil Kehutanan yang berasal dari Dana Reboisasi sebesar 40\% dibagi kepada kabupaten/ kota penghasil untuk mendanai kegiatan rehabilitasi hutan dan lahan.

b. Pertambangan Umum

Dana bagi hasil pertambangan umum berasal dari iuran tetap, iuran eksplorasi dan iuran eksploitasi. Dana bagi hasil pertambangan umum sebesar $80 \%$ yang berasal dari wilayah kabupaten/ kota dengan rincian, $16 \%$ untuk provinsi yang bersangkutan, $32 \%$ untuk kabupaten/ kota penghasil dan 32\% untuk kabupaten/ kota lainnya dalam provinsi yang bersangkutan. Dana bagi hasil pertambangan umum, dibagikan dengan porsi yang sama besar untuk seluruh kabupaten/ kota lainnya dalam provinsi yang bersangkutan.

Dana bagi hasil pertambangan umum yang berasal dari wilayah provinsi adalah sebesar $80 \%$ untuk provinsi yang bersangkutan dana bagi hasil pertambangan umum sebesar $80 \%$ yang berasal dari wilayah provinsi dengan rincian, $26 \%$ untuk provinsi yang bersangkutan dan $54 \%$ untuk kabupaten/ kota lainnya dalam provinsi yang bersangkutan. Dana bagi hasil pertambangan umum dibagikan dengan porsi yang sama besar untuk seluruh kabupaten/ kota lainnya dalam provinsi yang bersangkutan.

c. Perikanan

Dana bagi hasil Perikanan berasal dari pungutan Pengusahaan Perikanan dan Peungutan Hasil Perikanan. Dana bagi hasil Perikanan untuk daerah adalah sebesar $80 \%$ dibagikan dengan porsi yang sama besar untuk seluruh kabupaten kota/ kota.

d. Pertambangan Minyak Bumi

Dana bagi hasil pertambangan minyak bumi sebesar $15,5 \%$ berasal dari penerimaan Negara sumber daya alam pertambangan minyak bumi dari wilayah kabupaten/ kota yang bersangkutan setelah dikurangi komponen pajak dan pungutan lainnya. Dana bagi hasil pertambangan minyak bumi sebesar $15 \%$ dengan rincian, 3\% dibagikan untuk provinsi yang bersangkutan, 6\% dibagikan untuk kabupaten/ kota penghasil dan $6 \%$ dibagikan untuk seluruh kabupaten/ kota lainnya dalam provinsi yang bersangkutan. Dana bagi hasil Pertambangan Minyak Bumi sebesar 0,5\% dibagi dengan rincian, $0,1 \%$ untuk provinsi yang bersangkutan dan $0,2 \%$ untuk kabupaten/ kota lainya dalam provinsi yang bersangkutan. Dana bagi hasil Pertambangan Minyak Bumi dibagikan dengan porsi yang sama besar untuk seluruh kabupaten/ kota lainya dalam provinsi yang bersangkutan. Dana bagi hasil pertambangan minyak bumi sebesar $15,5 \%$ berasal dari penerimaan Negara sumber daya alam pertambangan minyak bumi dari wilayah provinsi yang bersangkutan setelah dikurangi komponen pajak dan pungutan lainya. Dana bagi hasil pertambangan minyak bumi sebagaimana dimaksud pada ayat (1) sebesar $15 \%$ dibagi dengan rincian, 5\% dibagikan untuk provinsi yang bersangkutan dan $10 \%$ dibagikan untuk kabupaten/ kota dalam provinsi yang bersangkutan. Dana bagi hasil Pertambangan Minyak sebesar 0,5\% dibagi dengan rincian, $0,17 \%$ dibagikan untuk provinsi yang bersangkutan dan $0,33 \%$ dibagikan untuk seluruh kabupaten/ kota dalam provinsi yang bersangkutan.

\section{e. Pertambangan Gas Bumi}

Dana bagi hasil Pertambangan gas bumi sebesar $30,5 \%$ berasal dari penerimaan negara sumber daya alam pertambangan gas komponen pajak dan pungutan lainya. Dana bagi hasil pertambangan gas bumi sebesar $30 \%$ dibagi dengan rincian, $6 \%$ dibagikan untuk provinsi yang bersangkutan, $12 \%$ dibagikan untuk kabupaten/ kota lainya dalam provinsi yang bersangkutan. Dana bagi hasil Pertambangan Gas Bumi sebesar 0,5\% dibagi 
dengan rincian, $0,1 \%$ untuk provinsi yang bersangkutan, $0,2 \%$ untuk kabupaten/ kota penghasil dan $0,2 \%$ untuk seluruh kabupaten/ kota lainya dalam provinsi yang bersangkutan. Dana bagi hasil Pertambangan Gas Bumi dibandingkan dengan porsi yang sama besar untuk seluruh kabupaten/ kota lainya dalam provinsi yang bersangkutan. Dana bagi hasil Pertambangan gas bumi sebesar 30,5\% berasal dari penerimaan Negara sumber daya alam pertambangan gas bumi dari wilayah provinsi yang bersangkutan setelah dikurangi komponen pajak dan pungutan lainya. Dana bagi hasil Pertambangan Gas Bumi sebesar 30\% dibagi dengan rincian, 10\% dibagikan untuk provinsi yang bersangkutan dan $20 \%$ dibagikan untuk seluruh kabupaten/ kota dalam proinsi yang bersangkutan. Dana bagi hasil Pertambangan Gas Bumi sebesar 0,5\% dibagi dengan rincian, $0,17 \%$ dibagikan untuk provinsi yang bersangkutan dan $0,33 \%$ dibagikan ke seluruh kabupaten/ kota dalam provinsi yang bersangkutan.

f. Pertambangan Panas Bumi

Penerimaan Negara yang berasal dari sumber daya alam pertambangan panas bumi dihasilkan dari wilayah daerah yang bersangkutan yang merupakan penerimaan Negara bukan pajak, dibagi dengan imbangan $20 \%$ untuk pemerintah dan $80 \%$ untuk daerah.

\section{Belanja Daerah}

Belanja daerah adalah semua pengeluaran kas daerah dalam periode tahunbersangkutan yang mengurangi kekayaan pemerintah daerah. Dalam struktur anggaran daerah dengan pendekatan kinerja, pengeluaran daerah dirinci menurut organisasi, fungsi, kelompok dan jenis belanja. Belanja daerah menurut organisasi adalah suatu kesatuan penggunaan seperti sekretariat daerah, dinas daerah, dan lembaga teknis daerah lainnya. Fungsi belanja misalnya pendidikan, kesehatan dan fungsi-fungsi lainnya.

Pengertian Belanja menurut Pernyataan Standar Akuntansi Pemerintahan No.2, (dalam Erlina, 2008) adalah Semua pengeluaran dari Rekening Kas Umum Negara/Daerah yang mengurangi saldo Anggaran lebih dalam periode tahun anggaran bersangkutan yang tidak akan diperoleh pembayarannya kembali oleh pemerintah. Sedangkan menurut Peraturan Menteri Dalam Negeri Nomor 21 Tahun 2011 tentang, Belanja Daerah didefenisikan sebagai kewajiban pemerintah daerah yang diakui sebagai pengurang nilai kekayaan bersih. Istilah belanja terdapat dalam laporan realisasi anggaran, karena dalam penyusunan laporan realisasi anggaran masih menggunakan basis kas. Belanja diklasifikasikan menurut klasifikasi ekonomi (jenis belanja), oganisasi dan fungsi. Klasifikasi ekonomi adalah pengelompokkan belanja yang didasarkan pada jenis belanja untuk melaksanakan suatu aktifitas. Klasifikasi belanja menurut Peraturan Pemerintah Nomor 71 tahun 2010 tentang standar akuntansi pemerintah untuk tujuan pelaporan keuangan menjadi:
1) Belanja Operasi

Belanja Operasi adalah pengeluaran anggaran untuk kegiatan sehari-hari pemerintah pusat / daerah yang member manfaat jangka pendek. Belanja Operasi meliputi:
a. Belanja Pegawai,
b. Belanja Barang,
c. Subsidi,
d. Hibah,
e. Bantuan Sosial.

2) Belanja Modal

Belanja Modal adalah pengeluaran anggaran untuk perolehan aset tetap berwujud yang memberi manfaat lebih dari satu periode akuntansi. Nilai aset tetap dalam belanja modal yaitu sebesar harga beli/bangunan aset ditambah seluruh belanja yang terkait dengan pengadaan/pembangunan aset sampai aset tersebut siap digunakan. Belanja Modal meliputi:

a. Belanja Modal Tanah,

b. Belanja Modal Peralatan dan Mesin,

c. Belanja Modal Gedung dan Bangunan,

d. Belanja Modal Jalan, Irigasi, dan Jaringan,

e. Belanja Modal Aset Tetap Lainnya,

f. Belanja Aset Lainnya.

3) Belanja Lain-Lain/Belanja Tidak Terduga

Belanja lain-lain atau belanja tak terduga adalah pengeluaran anggaran untuk kegiatan yang sifatnya tidak biasa dan tidak diharapkan berulang seperti penanggulangan bencana alam, bencana sosial, dan pengeluaran tidak terduga lainnya yang sangat diperlukan dalam rangka penyelenggaraan kewenangan pemerintah pusat/daerah.

4) Belanja Transfer.

Belanja Transfer adalah pengeluaran anggaran dari entitas pelaporan yang lebih tinggi ke entitas pelaporan yang lebih rendah seperti pengeluaran dana perimbangan oleh pemerintah provinsi ke kabupaten /kota serta dana bagi hasil dari kabupaten/kota ke desa.

\section{Hipotesis Penelitian}

Hipotesis merupakan jawaban sementara terhadap rumusan masalah penelitian, di mana rumusan masalah penelitian telah dinyatakan dalam bentuk kalimat pertanyaan. Dikatakan sementara, karena jawaban yang diberikan baru didasarkan pada teori yang relevan, belum didasarkan pada fakta-fakta empiris yang diperoleh melalui pengumpulan data. Jadi hipotesis juga dapat dinyatakan sebagai jawaban teoritis terhadap rumusan masalah penelitian, belum jawaban yang empirik. Adapun hipotesis dalam penelitian ini adalah sebagai berikut:

$\mathrm{H}_{1}$ : Diduga pendapatan asli daerah berpengaruh positif dan signifikan terhadap belanja daerah Kota Jayapura.

$\mathrm{H}_{2}$ : Diduga dana transfer berpengaruh positif dan signifikan terhadap belanja daerah Kota Jayapura.

$\mathrm{H}_{3}$ : Diduga pendapatan asli daerah dan dana transfer secara simultan berpengaruh positif dan 
signifikan terhadap belanja daerah Kota Jayapura.

\section{METODE PENELITIAN \\ Jenis Penelitian}

Penelitian kuantitatif merupakan penelitian yang berusaha memecahkan masalah dengan menggunakan angka, mulai dari pengumpulan data, penafsiran terhadap data tersebut serta penampilan serta penampilan dari hasilnya (Suharsimi, 2002). Penelitian kuantitatif bersifat konfirmasi dan deduktif, dimana penelitian ini mengkonfirmasi hasil penelitian sesuai teori yang sudah ada berdasarkan data ilmiah dalam bentuk angka. Penelitian kuantitatif juga bersifat deduktif yaitu menarik kesimpulan yang bersifat umum ke sesuatu yang bersifat khusus.

\section{Jenis dan Sumber Data}

Sumber data yang digunakan dalam penelitian ini adalah sumber data sekunder, di mana data yang diperoleh penulis merupakan data yang diperoleh secara tidak langsung, artinya data-data tersebut berupa data primer yang telah diolah lebih lanjut dan data yang disajikan oleh pihak lain. Menurut Sugiyono (2008:137) sumber sekunder adalah sumber yang tidak langsung memberikan data kepada pengumpul data, misalnya lewat orang lain atau dokumen.

Jenis data yang digunakan dalam penelitian ini adalah data sekunder yang diperoleh secara acak tidak langsung melalui perantara yang umumnya berupa bukti, catatan, atau laporan historis yang telah tersusun dalam arsip (data dokumenter) yang dipublikasikan dan yang tidak dipublikasikan. Sedangkan sumber data dalam penelitian ini adalah dari Badan Pengelola Keuangan dan Aset Daerah Kota Jayapura, dimana data yang digunakan adalah Laporan Realisasi Anggaran Kota Jayapura tahun 2010-2019.

\section{Teknik Pengumpulan Data}

Data yang digunakan dalam penelitian ini adalah data sekunder. Teknik pengumpulan data dalam penelitian ini adalah dengan teknik dokumentasi dengan cara mengumpulkan data-data berupa laporan target dan realisasi pendapatan daerah Kota Jayapura tahun 2015-2019. Pola penelitian ini dilakukan dengan dua tahap. Tahap pertama dilakukan melalui studi pustaka, yaitu melalui jurnal akuntansi dan buku-buku yang berkaitan dengan masalah yang diteliti. Tahap kedua, pengumpulan data sekunder yang diperoleh dari Badan Pengelola Keuangan dan Aset Daerah Kota Jayapura.

\section{Teknik Analisis Data}

\section{Analisis Regresi Linear Berganda}

Analisis data dalam penelitian ini adalah kuantitatif dengan menggunakan teknik perhitungan statistik. Analisis data yang diperoleh dalam penelitian ini akan menggunakan aplikasi SPSS (Statistical Product \& Service Solution). Metode analisis data yang digunakan dalam penelitian ini adalah dengan metode analisis Regresi Linear Berganda dengan persamaan dasar sebagai berikut:

Dimana:

$$
\mathrm{Y}=\mathrm{a}+\mathrm{b}_{1} \mathrm{X}_{1}+\mathrm{b}_{2} \mathrm{X}_{2}+\mathrm{e}
$$

$$
\begin{array}{ll}
\mathrm{Y} & =\text { Belanja Daerah } \\
\mathrm{a} & =\text { Konstanta } \\
\mathrm{X}_{1} & =\text { Pendapatan Asli Daerah } \\
\mathrm{X}_{2} & =\text { Dana Transfer } \\
\mathrm{b} & =\text { Koefisien Regresi } \\
\mathrm{e} & =\text { Error (Pengganggu) }
\end{array}
$$

(Ghozali, 2013)

\section{Pengujian Hipotesis}

\section{1) Uji t (Uji Secara Parsial)}

Uji t bertujuan untuk mengetahui pengaruh antara variabel independen dengan variabel dependen secara parsial. Untuk mengetahui apakah terdapat pengaruh yang signifikan dari masingmasing variabel independen terhadap variabel dependen, maka nilai signifikan $\mathrm{t}$ dibandingkan dengan derajat kepercayaannya. Apabila sig t lebih besar dari 0,05 maka tidak memiliki pengaruh secara pasial. Demikian pula sebaliknya jika sig t lebih kecil dari 0,05, maka ada pengaruh secara parsial. (Ghozali, 2013).

2) Uji F (Uji Secara Simultan)

Uji F dilakukan dengan tujuan untuk menguji keseluruhan variabel independen terhadap satu variabel dependen. Apabila Fhitung > Ftabel, maka variabel independen mempunyai pengaruh yang signifikan terhadap variabel dependen dengan menggunakan tingkat signifikan sebesar 0,05 jika nilai $F_{\text {hitung }}>F_{\text {tabel }}$ maka secara bersama-sama seluruh variabel independen mempengaruhi variabel dependen. Selain itu, dapat juga dengan melihat nilai probabilitas. Jika nilai probabilitas lebih kecil daripada 0,05 (untuk tingkat signifikansi $=0,05$ ), maka variabel independen secara bersama-sama berpengaruh terhadap variabel dependen. Sedangkan jika nilai probabilitas lebih besar daripada 0,05. (Ghozali, 2013).

\section{3) Koefisien Korelasi}

Koefisien korelasi adalah nilai yang menunjukan kuat/tidaknya hubungan linier antar dua variabel. Koefisien korelasi biasa dilambangkan dengan huruf $r$ dimana nilai $r$ dapat bervariasi dari -1 sampai +1 . Nilai $r$ yang mendekati -1 atau +1 menunjukan hubungan yang kuat antara dua variabel tersebut dan nilai $r$ yang mendekati 0 mengindikasikan lemahnya hubungan antara dua variabel tersebut. Sedangkan tanda + (positif) dan - (negatif) memberikan informasi mengenai arah hubungan antara dua variabel tersebut. Jika 
bernilai + (positif) maka kedua variabel tersebut memiliki hubungan yang searah. Dalam arti lain peningkatan $X$ akan bersamaan dengan peningkatan $\mathrm{Y}$ dan begitu juga sebaliknya. Jika bernilai (negatif) artinya korelasi antara kedua variabel tersebut bersifat berlawanan. Peningkatan nilai $\mathrm{X}$ akan dibarengi dengan penurunan Y. (Sugiyono, 2014)

4) Koefisien Determinasi (Adjusted $\boldsymbol{R}^{2}$ )

Koefisien Determinasi $\left(\mathrm{R}^{2}\right)$ dimaksudkan untuk mengukur kemampuan seberapa besar presentase variabel independen pada model regresi berganda dalam menjelaskanvariabel dependen. Nilai koefisien determinasi adalah antara 0 dan 1 . Nilai $\mathrm{R}^{2}$ yang kecil berarti kemampuan variabelvariabel independen dalam menjelaskan variasi variabel dependen amat terbatas. Nilai yang mendekati 1 berarti variabel independen memberikan hamper semua informasi yang dibutuhkan untuk memprediksi variabel dependen. Kriteria koefisien determinasi dapat dilihat pada tabel berikut ini:

\section{Hasil Penelitian}

1. Pendapatan Asli Daerah, Dana Transfer dan Belanja Daerah Kota Jayapura

\section{1) Pendapatan Asli Daerah Kota Jayapura 2010-2019}

Menurut Undang-Undang No. 25 tahun 1999, pendapatan asli daerah merupakan semua penerimaan daerah yang berasal dari potensi sumber daya yang ada di daerah. Sumber-sumber pendapatan asli daerah meliputi hasil pajak daerah, hasil retribusi daerah, hasil perusahaan milik daerah dan hasil pengelolaan kekayaan daerah lainnya yang dipisahkan, lain-lain pendapatan asli daerah yang sah. Adapun data pendapatan asli daerah Kota Jayapura tahun 2010-2019 adalah sebagai berikut:

Pendapatan Asli Daerah Kota Jayapura tahun 2010-2019

\begin{tabular}{|c|c|c|}
\hline Tahun & $\begin{array}{c}\text { Pendapatan Asli } \\
\text { Daerah (Rp) }\end{array}$ & $\begin{array}{c}\text { Perkembangan } \\
(\%)\end{array}$ \\
\hline 2010 & 52.698 .546 .054 & \\
\hline 2011 & 43.039 .239 .217 & $(22)$ \\
\hline 2012 & 78.138 .312 .941 & 45 \\
\hline 2013 & 103.430 .111 .932 & 24 \\
\hline 2014 & 147.103 .021 .595 & 30 \\
\hline 2015 & 152.631 .134 .983 & 4 \\
\hline 2016 & 164.831 .615 .678 & 7 \\
\hline 2017 & 176.666 .250 .173 & 7 \\
\hline 2018 & 243.863 .618 .164 & 28 \\
\hline 2019 & 235.147 .029 .262 & $(4)$ \\
\hline
\end{tabular}

Sumber: Laporan Realisasi Anggaran

Kota Jayapura, 2021
Tabel di atas menunjukkan bahwa selama tahun 2010 sampai dengan tahun 2019, pendapatan asli daerah Kota Jayapura cenderung mengalami kenaikan, walaupun pada tahun 2011 dan 2019 realisasi penerimaan pendapatan asli daerah Kota Jayapura mengalami penurunan.

\section{2) Data Transfer Kota Jayapura 2010-2019}

Dana transfer atau pendapatan asli daerah merupakan sumber pendapatan daerah yang berasal dari Anggaran Pendapatan dan Belanja Negara untuk mendukung pelaksanaan kewenangan pemerintah daerah dalam mencapai tujuan pemberian otonomi kepada daerah, terutama peningkatan pelayanan dan kesejahteraan masyarakat yang semakin baik. Pendapatan asli daerah meliputi Dana Alokasi Khusus (DAK) yang digunakan untuk membiayai proyek-proyek pemerintah, Dana Alokasi Umum (DAU) yang digunakan untuk membiayai gaji pegawai, dan Dana Bagi Hasil Pajak/Bukan Pajak yang digunakan untuk mengatasi masalah ketimpangan vertikal (antara Pusat dan Daerah). Adapan data realisasi penerimaan dana transfer Kota Jayapura tahun 2010 sampai dengan tahun 2019 dapat dilihat pada tabel berikut ini:

Dana Transfer Kota Jayapura Tahun $2010-2019$

\begin{tabular}{|c|c|c|}
\hline Tahun & $\begin{array}{c}\text { Dana Transfer } \\
(\mathrm{Rp})\end{array}$ & $\begin{array}{c}\text { Perkembanga } \\
\mathrm{n} \\
(\%)\end{array}$ \\
\hline 2010 & 593.738 .052 .733 & \\
\hline 2011 & 424.313 .899 .568 & $(40)$ \\
\hline 2012 & 700.372 .434 .085 & 39 \\
\hline 2013 & 699.475 .449 .839 & $(0)$ \\
\hline 2014 & 901.862 .316 .516 & 22 \\
\hline 2015 & 944.779 .914 .612 & 5 \\
\hline 2016 & 1.113 .882 .688 .95 & 15 \\
7 & 1.046 .127 .433 .20 \\
9 & $(6)$ \\
\hline 2017 & 1.020 .212 .686 .61 & $(3)$ \\
\hline 2018 & 1.035 .009 .905 .54 & 1 \\
\hline 2019 & 8
\end{tabular}

Sumber: Laporan Realisasi Anggaran Kota Jayapura, 2021

Tabel di atas menunjukkan bahwa selama tahun 2010 sampai dengan tahun 2019, realisasi penerimaan dana transfer Kota Jayapura berfluktuasi. Besarnya realisasi dana transfer ke daerah ditentukan dengan beberapa ketentuan diantaranya dihitung berdasarkan formula tertentu, berdasarkan daerah penghasil (memiliki keayaan alam) maka daerah tersebut akan mendapatkan kembali dalam bentuk bagi hasil apabila ada 
penerimaan negaranya, dan berdasarkan kinerja daerah tersebut.

3) Belanja Daerah Kota Jayapura 2010-2019

Belanja daerah adalah semua kewajiban pemerintah daerah yang diakui sebagai pengurang nilai kekayaan bersih dalam periode tahun anggaran berkenaan. Rencana belanja daerah disusun setiap tahun melalui Anggaran Pendapatan dan Belanja Daerah (APBD). Adapun belanja daerah Kota Jayapura tahun 2010 sampai dengan tahun 2019 adalah sebagai berikut:

Tabel 4.3

Belanja Daerah Kota Jayapura Tahun 2010 2019

\begin{tabular}{|c|c|c|}
\hline Tahun & $\begin{array}{c}\text { Belanja Daerah } \\
(\mathrm{Rp})\end{array}$ & $\begin{array}{c}\text { Perkembangan } \\
(\%)\end{array}$ \\
\hline 2010 & 639.850 .519 .817 & $(64)$ \\
\hline 2011 & 389.124 .717 .329 & 51 \\
\hline 2012 & 795.461 .218 .498 & 16 \\
\hline 2013 & 950.906 .793 .019 & 12 \\
\hline 2014 & 1.077 .369 .145 .242 & 11 \\
\hline 2015 & 1.204 .819 .811 .826 & 6 \\
\hline 2016 & 1.280 .379 .079 .575 & $(8)$ \\
\hline 2017 & 1.187 .042 .622 .291 & $(4)$ \\
\hline 2018 & 1.136 .467 .522 .886 & $(0)$ \\
\hline 2019 & 1.134 .115 .360 .472 & Sumber: LRA Kota Jayapura, 2021 \\
Belanja daerah Kota Jayapura pada \\
mengalami penurunan sebesar
\end{tabular}

Tabel 4.4
64\%, sedangkan pada tahun 2012-2016 cenderung mengalami kenaikan. Akan tetapi pada tahun 2017-2019 kembali mengalami penurunan, namun tidak terlalu signifikan. Berdasarkan hasil identifikasi Kementerian Dalam Negeri (2021) mengemukakan bahwa faktor penyebab rendahnya realisasi belanja daerah dikarenakan; masih adanya sisa dana penghematan/pelaksanaan program kegiatan dan sisa Dana Transfer yang belum digunakan, adanya kelebihan target pajak daerah dan retribusi daerah tahun sebelumnya, belum disalurkannya bagi hasil pajak provinsi pada kabupaten/kota, belum dibayarkannya kewajiban kepada pihak ketiga atas belanja tahun anggaran sebelumnya, terdapat sisa dana Pemda yang masih menunggu audit BPK-RI, kehati-hatian kepala daerah termasuk daerah yang menggelar Pilkada 2020 dalam membelanjakan Anggaran Pendapatan dan Belanja Daerah di era pandemi karena menghindari permasalahan hukum di kemudian hari.

\section{4) Analis Regresi Berganda (Multiple} Regression Analys)

Regresi berganda ditujukan untuk menentukan hubungan linear antar beberapa variabel bebas $X_{1}$ dan $\mathrm{X}_{2}$, dengan variabel terikat $\mathrm{Y}$. Berdasarkan hasil pengolahan data dalam penelitian ini, maka diperoleh hasil sebagai berikut:

Hasil Regresi Berganda

\begin{tabular}{|c|c|c|c|c|c|}
\hline \multirow[t]{2}{*}{ Model } & \multicolumn{2}{|c|}{$\begin{array}{l}\text { Unstandardized } \\
\text { Coefficients }\end{array}$} & $\begin{array}{l}\text { Standardized } \\
\text { Coefficients }\end{array}$ & \multirow[t]{2}{*}{$\mathrm{t}$} & \multirow[t]{2}{*}{ Sig. } \\
\hline & $\mathrm{B}$ & Std. Error & Beta & & \\
\hline \multirow{3}{*}{$\begin{array}{l}\text { (Constant) } \\
\text { Pendapatan Asli Daerah } \\
\text { Dana Transfer }\end{array}$} & $-2,208$ & 2,347 & &,- 941 & ,378 \\
\hline &,- 043 &, 179 &,- 070 &,- 240 & ,817 \\
\hline & 1,230 & ,347 & 1,033 & 3,550 & ,009 \\
\hline
\end{tabular}

a. Dependent Variable: Belanja Daerah

Sumber: Output SPSS, 2021

Persamaan regresi linier berganda yang digunakan dalam penelitian adalah sebagai berikut :

$\mathrm{Y}=-2,208-0,043 \mathrm{X}_{1}+1,230 \mathrm{X}_{2}$

Dari persamaan regresi diatas dapat diartikan sebagai berikut:

a. Nilai konstanta (a) sebesar -2,208 berarti bahwa jika pendapatan asli daerah $\left(\mathrm{X}_{1}\right)$ dan dana transfer $\left(\mathrm{X}_{2}\right)$ nilainya adalah 0 , maka belanja daerah (Y) akan mengelami penurunan sebesar 2,208.

b. Koefisien pendapatan asli daerah $\left(\mathrm{X}_{1}\right)$ adalah $-0,043$ yang artinya setiap kenaikan pendapatan asli daerah sebesar 1 satuan dan nilai dari variabel lainnya tetap (konstan), maka belanja daerah Kota Jayapura akan mengalami penurunan sebesar 0,043.

c. Koefisien dana transfer $\left(\mathrm{X}_{2}\right)$ adalah 1,230 yang artinya setiap kenaikan dana transfer sebesar 1 satuan dan nilai dari variabel lainnya tetap (konstan), maka belanja daerah Kota Jayapura akan mengalami kenaikan sebesar 1,230.

\section{5) Koefisien Korelasi dan Koefisien} Determinasi

Uji koefisien korelasi digunakan untuk mengukur seberapa besar hubungan linier variabel bebas yang diteliti terhadap variabel terikat. Sedangkan Uji koefisien 
korelasi digunakan untuk mengukur seberapa jauh kemampuan model dalam menerangkan variasi variabel terikat.
Berdasarkan hasil pengolahan data dengan menggunakan SPSS for Windows, diperoleh hasil sebagai berikut:

Tabel 4.5

Model Summary

\begin{tabular}{|c|c|c|c|c|}
\hline Model & $\mathrm{R}$ & $\mathrm{R}$ Square & $\begin{array}{c}\text { Adjusted R } \\
\text { Square }\end{array}$ & $\begin{array}{c}\text { Std. Error of the } \\
\text { Estimate }\end{array}$ \\
\hline 1 &, $967^{\mathrm{a}}$ &, 936 &, 917 & 0,04647 \\
\hline
\end{tabular}

a. Predictors: (Constant), Dana Transfer, Pendapatan Asli Daerah

b. Dependent Variable: Belanja Daerah

Sumber: Output SPSS, 2021

Dari output SPSS di atas, diketahui nilai koefisien korelasi sebesar 0,967 nilai tersebut mengandung arti bahwa variabel bebas dalam hal ini pendapatan asli daerah dan dana transfer memiliki hubungan yang sangat kuat dengan variabel terikat belanja daerah Kota Jayapura. Sedangkan nilai koefisien determinan (Adjusted $R$ Square) sebesar 0,917 atau sebesar $91,7 \%$ menunjukkan bahwa pendapatan asli daerah dan dana transfer memiliki kontribusi pengaruh yang sangat besar terhadap belanja daerah Kota Jayapura. Atau dengan kata lain, pendapatan asli daerah dan dana transfer memberikan kontribusi pengaruh terhadap belanja daerah Kota Jayapura sebesar 91,7\% sedangkan sisanya dipengaruhi oleh variabel lain yang tidak diteliti dalam penelitian ini.

6) Pengujian Hipotesis Penelitian

a. Uji Signifikansi Parsial (Uji-t)

Pengujian ini dilakukan untuk menguji hipotesis pertama, kedua dan ketiga guna mengetahui apakah setiap variabel independen secara parsial mempunyai pengaruh signifikan atau tidak terhadap variabel dependen.

Berdasarkan hasil analisis regresi berganda pada tabel 4.4 dapat diketahui bahwa nilai $t_{\text {hitung }}$ variabel $\mathrm{X}_{1}$ (pendapatan asli daerah) adalah sebesar $=-0,240$ dengan sig. $=0,817$, dan nilai $t_{\text {hitung }}$ variabel $\mathrm{X}_{2}$ (dana transfer) adalah sebesar $=3,550$ dengan sig. $=0,009$. Nilai $t_{\text {tabel }}$ pada df $=7$ adalah sebesar 2,36462. Dengan demikian, maka dapat disimpulkan bahwa:

a) Variabel $X_{1}$ (pendapatan asli daerah) berpengaruh negatif tidak signifikan terhadap belanja daerah Kota Jayapura, karena nilai $t_{\text {hitung }}$ lebih kecil dari nilai $t_{\text {tabel }}(-0,240<$ 2,36462) dan nilai sig. lebih besar dari alfa $(0,817>0,05)$, dengan demikian maka hipotesis pertama ditolak.

b) Variabel $\mathrm{X}_{2} \quad$ (dana transfer) berpengaruh positif dan signifikan terhadap belanja daerah Kota Jayapura, karena nilai $t_{\text {hitung }}$ lebih kecil dari nilai $t_{\text {tabel }}(3,550<2,36462)$ dan nilai sig. lebih kecil dari alfa $(0,009<0,05)$, dengan demikian maka hipotesis kedua diterima.

\section{b. Uji Signifikansi Simultan (Uji-F)}

Uji F-statistik digunakan untuk menguji hipotesis ketiga, yaitu diduga pendapatan asli daerah dan dana transfer berpengaruh positif dan signifikan secara simultan terhadap belanja daerah Kota Jayapura. Maka berdasarkan hasil pengolahan data dengan menggunakan aplikasi SPSS for Windows, diperoleh hasil sebagai berikut:

Tabel 4.6

Hasil Uji Simultan

\begin{tabular}{|c|c|c|c|c|c|c|}
\hline & Model & $\begin{array}{l}\text { Sum of } \\
\text { Squares }\end{array}$ & df & $\begin{array}{l}\text { Mean } \\
\text { Square }\end{array}$ & $\mathrm{F}$ & Sig. \\
\hline \multirow{3}{*}{1} & Regression &, 220 & 2 & \multirow{3}{*}{$\begin{array}{r}, 110 \\
, 002\end{array}$} & \multirow[t]{3}{*}{50,856} & \multirow[t]{3}{*}{, $000^{\mathrm{b}}$} \\
\hline & Residual &, 015 & 7 & & & \\
\hline & Total & ,235 & 9 & & & \\
\hline
\end{tabular}

a. Dependent Variable: Belanja Daerah

b. Predictors: (Constant), Dana Transfer, Pendapatan Asli Daerah

Sumber: Output SPSS, 2021

Berdasarkan data pada tabel 4.6, maka dapat diketahui bahwa nilai $F_{\text {hitung }}$ adalah sebesar 50,856 dengan $\mathrm{F}_{\text {sign }}$ sebesar 0,000. Nilai $F_{\text {tabel }}$ dengan jumlah sampel 10 dengan df1 $=2$ dan df $2=7$ adalah 4,74. Berdasarkan ketentuan uji simultan, maka dapat disimpulkan bahwa pendapatan asli

daerah dan dana transfer secara simultan berpengaruh positif dan signifikan terhadap belanja daerah Kota Jayapura. Dengan demikian maka hipotesis ketiga tentang "Diduga pendapatan asli daerah dan dana transfer berpengaruh positif dan signifikan secara simultan terhadap belanja daerah Kota 
Jayapura" diterima, karena nilai $\mathrm{F}_{\text {hitung }}$ lebih besar dari nilai $\mathrm{F}_{\text {tabel }}(50,856>4,74)$, dan nilai signifikan sebesar $0,000<0,05$.

\section{Pembahasan}

1. Pengaruh Pendapatan asli daerah terhadap Belanja daerah Kota Jayapura

Setelah melakukan analisis dan pengujian hipotesis, ditemukan bahwa pendapatan asli daerah berpengaruh negatif tidak signifikan terhadap belanja daerah Kota Jayapura. Hal ini berarti bahwa Kota Jayapura telah mendapatkan pendapatan asli daerah yang lumayan besar, akan tetapi belum mampu memberikan kontribusi terhadap belanja daerah, karena porsi pendapatan asli daerah masih sangat kecil untuk digunakan dalam membiayai belanja daerah dibandingkan dengan penerimaan dana transfer. Idealnya belanja pemerintah daerah dapat dicukupi dengan menggunakan pendapatan asli daerahnya. Akan tetapi, realitanya menunjukkan yang terjadi selama ini bahwa pendapatan asli daerah belum mampu dipergunakan secara maksimal untuk belanja daerah.

Hasil penelitian ini bertolak belakang dengan hasil penelitian terdahulu yang dilakukan oleh Rahma Wati dan Catur Martian Fajar (2017), Nabiyatun Nur Fatimah, Anita Nopiyanti, dan Danang Mintoyuwono (2019), Ang Sandera Widjajakoesoema (2011), Wildan Dwi Dermawan (2017). Dimana dalam penelitianpenelitian terdahulu tersebut menunjukkan bahwa pendapatan asli daerah berpengaruh terhadap belanja daerah.

Pendapatan asli daerah merupakan representasi dari pendapatan yang dihasilkan oleh daerah. Pemerintah daerah harus lebih mengoptimalkan pendapatan asli daerahnya agar dapat membiayai pengeluaran daerah dan tidak menghambat kegiatan ekonomi di daerah yang bersangkutan. Semakin besar pendapatan asli daerah akan membuat belanja daerah juga meningkat dan akan lebih banyak pengeluaran untuk kesejahteraan masyarakat. Sejalan dengan hal tersebut, maka semakin besar kemampuan daerah dalam mengumpulkan pendapatan asli daerah akan semakin longgar alokasi belanja daerah, sehingga terdapat hubungan yang positif antara pendapatan asli daerah dengan belanja daerah.

Menurut Undang-Undang No. 25 tahun 1999, pendapatan asli daerah merupakan semua penerimaan daerah yang berasal dari potensi sumber daya yang ada di daerah. Sumber-sumber pendapatan asli daerah meliputi hasil pajak daerah, hasil retribusi daerah, hasil perusahaan milik daerah dan hasil pengelolaan kekayaan daerah lainnya yang dipisahkan, lain-lain pendapatan asli daerah yang sah. Pendapatan asli daerah adalah pendapatan yang diperoleh dari sumbersumber pendapatan daerah dan dikelola sendiri oleh pemerintah daerah. Pendapatan asli daerah merupakan tulang punggung pembiayaan daerah, oleh karenanya kemampuan melaksanakan ekonomi diukur dari besarnya kontribusi yang diberikan oleh Pendapatan Asli Daerah terhadap Anggaran Pendapatan dan Belanja Daerah, semakin besar kontribusi yang dapat diberikan oleh Pendapatan Asli Daerah terhadap Anggaran Pendapatan dan Belanja Daerah berarti semakin kecil ketergantungan Pemerintah daerah terhadap bantuan Pemerintah pusat.

2. Pengaruh Dana transfer terhadap Belanja daerah Kota Jayapura

Hipotesis terkait dana transfer terhadap belanja daerah kota Jayapura adalah bahwa dana transfer berpengaruh positif dan signifikan terhadap belanja daerah Kota Jayapura. Hasil penelitian ini sejalan dengan hasil penelitian terdahulu yang dilakukan oleh Rahma Wati dan Catur Martian Fajar (2017), Nabiyatun Nur Fatimah, Anita Nopiyanti, dan Danang Mintoyuwono (2019), Ang Sandera Widjajakoesoema (2011), Wildan Dwi Dermawan (2017). Dimana dalam penelitian-penelitian terdahulu tersebut menunjukkan bahwa dana transfer berpengaruh signifikan terhadap belanja daerah.

Menurut Djaenuri (2012:100), dana transfer merupakan sumber pendapatan daerah yang berasal dari Anggaran Pendapatan dan Belanja Negara untuk mendukung pelaksanaan kewenanangan pemerintah daerah dalam mencapai tujuan pemberian otonomi kepada daerah, terutama peningkatan pelayanan dan kesejahteraan masyarakat yang semakin baik. Dengan demikian, sejalan dengan tujuan pokoknya, dana transfer dapat lebih memperdayakan dan meningkatkan kemampuan perekonomian daerah, menciptakan sistem pembayaran yang adil, proporsional, rasional, transparan partisipatif, bertanggungjawab (akuntabel), serta memberikan kepastian sumber keuangan daerah yang berasal dari wilayah daerah yang bersangkutan.

Dana transfer atau dana perimbangan merupakan sumber pendapatan daerah yang berasal dari Anggaran Pendapatan Dan Belanja Daerah untuk mendukung pelaksanaan kewenangan pemerintah daerah dalam mencapai tujuan pemberian otonomi kepada daerah, terutama peningkatan pelayanan dan kesejahteraan masyarakat yang semakin baik. Dana transfer meliputi Dana Alokasi Khusus (DAK) yang digunakan untuk membiayai proyek-proyek pemerintah, Dana Alokasi Umum (DAU) yang digunakan untuk membiayai gaji pegawai, dan Dana Bagi Hasil Pajak/Bukan Pajak yang digunakan untuk mengatasi masalah ketimpangan vertikal (antara Pusat dan Daerah). Dengan demikian, semakin tinggi penerimaan dana transfer, maka akan berpengaruh pada besar kecilnya realisasi belanja daerah.

3. Pengaruh Pendapatan asli daerah dan Dana transfer secara simultan terhadap Belanja Daerah Kota Jayapura

Hasil uji F menunjukkan bahwa pendapatan asli daerah dan dana transfer secara simultan berpengaruh positif dan signifikan terhadap kemandirian keuangan daerah Kota 
Jayapura. Hasil penelitian ini sejalan dengan hasil penelitian yang dilakukan oleh Rahma Wati dan Catur Martian Fajar (2017), Nabiyatun Nur Fatimah, Anita Nopiyanti, dan Danang Mintoyuwono (2019), dan Ang Sandera Widjajakoesoema (2011).

Hasil ini diperkuat dengan hasil uji koefisien korelasi yang menunjukkan bahwa variabel bebas dalam hal ini pendapatan asli daerah dan dana transfer memiliki hubungan yang sangat kuat dengan variabel belanja daerah. Sama halnya dengan nilai koefisien determinan yang menunjukkan bahwa pendapatan asli daerah dan dana transfer memberikan kontribusi pengaruh yang sangat besar yaitu sebesar 91,7\% terhadap belanja daerah Kota Jayapura. Hal ini menggambarkan bahwa besarnya penerimaan pendapatan asli daerah dan dana transfer di setiap tahunnya, akan sangat mempengaruhi besar kecilnya realisasi belanja daerah.

Sumber penerimaan daerah, selain bersumber dari pendapatan asli daerah juga bersumber dari dana transfer atau dana perimbangan. Pendapatan Asli Daerah merupakan sumber pendapatan daerah yang berasal dari kegiatan ekonomi daerah itu sendiri. Sedangkan dana transfer bersumber dari anggaran pendapatan dan belanja negara. Kedua sumber penerimaan daerah ini merupakan tulang punggung daerah dalam memenuhi kebutuhan/kewajiban daerah.

\section{PENUTUP}

\section{Kesimpulan}

Berdasarkan hasil analisis pada bab sebelumnya, maka penulis menarik beberapa kesimpulan sebagai berikut:

1. Hasil uji parisal menunjukkan bahwa pendapatan asli daerah berpengaruh negatif tidak signifikan terhadap belanja daerah Kota Jayapura. Hal ini dibuktikan dengan nilai $t_{\text {hitung }}$ lebih kecil dari nilai $t_{\text {tabel }}$ dan nilai signifikan lebih besar dari nilai alfa.

2. Hasil uji parisal menunjukkan bahwa dana transfer berpengaruh positif dan signifikan terhadap belanja daerah Kota Jayapura. Hal ini dibuktikan dengan nilai $\mathrm{t}_{\text {hitung }}$ lebih besar dari nilai $\mathrm{t}_{\text {tabel }}$ dan nilai signifikan lebih kecil dari nilai alfa.

3. Hasil uji simultan menunjukkan bahwa pendapatan asli daerah dan dana tranfer berpengaruh posifiti dan signifikan secara simultan terhadap belanja daerah Kota Jayapura. Hal ini dibuktikan dengan nilai $F_{\text {hitung }}$ lebih besar dari nilai $\mathrm{F}_{\text {tabel }}$ dan nilai signifikan lebih kecil dari nilai alfa.

\section{Saran}

Adapun sara-saran yang dapat disampaikan penulis melalui hasil penelitian ini adalah sebagai berikut:
1. Pemerintah Daerah Kota Jayapura diharapkan tidak berharap terlalu besar kepada pemerintah pusat dalam hal penerimaan Dana Perimbang, akan tetapi bisa terus menggali sumber-sumber Pendapatan Asli Daerah (PAD) secara intensif untuk meningkatkan pendapatan asli daerah.

2. Variabel yang digunakan dalam penelitian yang akan datang diharapkan lebih lengkap dan bervariasi dengan menambah variabel-variabel independen lain, baik ukuran-ukuran atau jenis penerimaan pemerintah daerah lainnya, maupun variabel non-keuangan seperti kebijakan pemerintah, kondisi makro ekonomi.

\section{DAFTAR PUSTAKA}

Abimanyu, Anggito. (2005) Format Anggaran Terpadu Menghilangkan Tumpang Tindih. BAPEKKI Depkeu

Ang Sandera Widjajakoesoema (2011) Pengaruh Pendapatan Asli Daerah (PAD) Terhadap Belanja Daerah Pemerintah Kota Kediri, Jurnal Cahaya Aktiva Vol.01 No.01, Politeknik Cahaya Surya Kediri

Arikunto, Suharsimi. (2002) Metodologi Penelitian. Penerbit PT. Rineka Cipta. Jakarta

Awaniz, Berlian Nur (2011) Pengaruh Dana Alokasi Umum (DAU) dan Pendapatan Asli Daerah (PAD) terhadap Belanja Daerah di Eks Karasidenan Pekalongan. Skripsi. Universitas Negeri Semarang. Semarang.

Bahar, Ujang. (2009). Otonomi Daerah Terhadap Pinjaman Luar Negeri PT.Indeks: Jakarta

Bastian, Indra. (2006) Akuntansi Sektor Publik: Suatu Pengantar. Jakarta: Erlangga

Darise, N. (2008) Akuntansi Keuangan Daerah, Jakarta: PT Indeks

Djaenuri, Aries (2012). Hubungan Keuangan PusatDaerah, Ghalia Indonesia,. Jakarta

Efendi Jikwa, Agustinus Salle, dan Paulus K. Allo Layuk (2017) Pengaruh Pendapatan Transfer Dan Silpa Terhadap Belanja Modal Di Kabupaten Mamberamo Tengah, Jurnal Keuda Vol. 2 No. 2, Program Pascasarjana Keuangan Daerah, Universitas Cenderawasih Jayapura

Erlina. (2008) Pengaruh Transfer Pemerintah Pusat Terhadap Belanja Modal Pemerintah Kabupaten/Kota Di Sumatra Utara. Jurnal Akuntansi

Ghozali, Imam. (2013) Aplikasi Analisis Multivariat dengan Program IBM SPSS. Edisi 7. Semarang: Penerbit Universitas Diponegoro

Ghozali, Imam. (2016) Aplikasi Analisis Multivariete Dengan Program. IBM SPSS 23 (Edisi 8). Cetakan ke VIII. Semarang : Badan Penerbit Universitas Diponegoro, Semarang

Halim, Abdul (2004) Akuntansi Keuangan Daerah, Penerbit Salemba Empat, Jakarta 
Halim, Abdul (2007) Akuntansi Sektor Publik: Akuntansi Keuangan Daerah. Jakarta : Salemba Empat

Halim, Abdul (2016) Manajemen Keuangan Sektor Publik. Penerbit Salemba · Empat, Jakarta

Halim, Abdul dan Jamal Abdul Nasir. (2006) Kajian tentang Keuangan Daerah Pemerintah Kota Malang. Jurnal Manajemen Usahawan. Hal 42. Nomor 06

Halim. Abdul (2014) Akuntansi Sektor Publik Akuntansi. Keuangan Daerah, Edisi Empat, Salemba. Empat, Jakarta

Indraningrum Tri. (2011) Pengaruh Pendapatan Asli Daerah (PAD) Dan Dana Alokasi Umum (DAU) Terhadap Belanja Langsung (Studi Pada Pemerintah Daerah Kabupaten/Kota Di Provinsi Jawa Tengah), Skripsi Fakultas Ekonomi Universitas Diponegoro,Semarang.

Kuncoro, Haryo. (2007) Fenomena Flypaper Effect pada Kinerja Keuangan Pemerintah Daerah Kota dan Kabupaten di Indonesia. Simposium Nasional Akuntansi X. Unhas Makassar

Machfud Sidik. (2000) Optimalisasi Pajak Daerah Dalam Rangka Meningkatkan Keuangan Daerah, STIA LAN, Bandung

Mandala Harefa, Sony Hendra Permana, Dewi Restu Mangeswuri, Hilma Meilani, (2017), Optimalisasi Kebijakan Penerimaan Daerah, Yayasan Pustaka Obor Indonesia Jakarta

Mardiasmo, (2002) Otonomi dan Manajemen Keuangan Daerah. Penerbit Andi. Yogyakarta

Mardiasmo. (2007). Akuntansi Sektor Publik. Yogyakarta : Andi

Masayu Rahma Wati dan Catur Martian Fajar, (2017) Pengaruh Pendapatan Asli Daerah Dan Dana Perimbangan Terhadap Belanja Daerah Kota Bandung, Jurnal Kajian Akuntansi, Vol 1, (1), 2017, 63-76, Fakultas Ekonomi Universitas BSI

Nabiyatun Nur Fatimah, Anita Nopiyanti, dan Danang Mintoyuwono (2019) Pengaruh Pendaptan Asli Daerah Dan Dana Perimbangan Terhadap Belanja Daerah, Jurnal Equity, Vol 22, No. 2, Universitas Pembangunan Nasional "Veteran" Jakarta

Nam, Chan Woon dan Parsche, Rudiger. (2002) Looking for Appropriate forms of Intergovernmental Transfers for Municipalities in Transition Economies. Makalah disajikan dalam 42nd Congress of the European Regional Science Association (ERSA), Dortmund, 27-31 Agustus 2002.

Oates, W E. (1999). An Essay on fiscal federal-ism. Journal of Economic Literature, 37(3): 1120-1149.

Peraturan Menteri Dalam Negeri No.32 Tahun 2008

Peraturan Menteri Dalam Negeri Nomor 21 Tahun 2011 tentang, Belanja Daerah

Peraturan Pemerintah Nomor 58 Tahun 2005 tentang Pengelolaan Keuangan Daerah

Rasul, Syahrudin. (2006) Pengintegrasian Sistem Akuntabilitas Kinerja dan anggaran dalam
Perspektif UU NO. 17/2003 Tentang Keuangan Negara. Jakarta: PNRI

Santoso, S. (2002) SPSS Versi 11.5 Cetakan Kedua: Gramedia, Jakarta

Saragih, Juli Panglima. (2003) Desentralisasi Fiskal dan Keuangan Daerah dalam Otonomi. Cetakan Pertama. Penerbit Ghalia Indonesia: Jakarta

Sidik, Machfud, (2002) Perimbangan Keuangan Pusat dan Daerah sebagai Pelaksanaan Desentralisasi Fiskal (antara Teori dan Aplikasinya di Indonesia). Seminar "Setahun Implementasi Kebijaksanaan Otonomi Daerah di Indonesia"

Sugiyono. (2008) Metode Penelitian Kuantitatif Kualitatif dan $R \& D$. Bandung : Alfabeta

Sugiyono. (2014) Metode Penelitian Kuantitatif Kualitatif dan $R \& D$. Bandung : Alfabeta

Undang-Undang no. 12 tahun 1994 tentang Pajak Bumi dan Bangunan

Undang-Undang No. 20 tahun 2000 tentang Biaya Perolehan Hak Atas Tanah dan Bangunan.

Undang-Undang No. 55 tahun 2005 tentang Dana Perimbangan

Undang-Undang No. 58 tahun 2005 tentang Pengelolaan keuangan Daerah.

Undang-Undang Nomor 25 tahun 1999 tentang Perimbangan Keuangan Antara Pemerintah Pusat dan Daerah

Undang-Undang Nomor 32 Tahun 2004 tentang Pemerintah Daerah

Undang-Undang Nomor 33 tahun 2004 tentang Perimbangan Keuangan antara Pemerintah dan Pemerintahan Daerah mencabut

Undang-Undang U No. 7 tahun 1982 tentang Pajak Penghasilan

UU No. 33 Tahun 2004 tentang perimbangan antara pemerintah pusat dan daerah

UU Nomor 33 Tahun 2004 tentang Perimbangan Keuangan antara Pemerintah Pusat dan Pemerintah Daerah

Wildan Dwi Dermawan (2017) Pengaruh Pendapatan Asli Daerah (Pad) Terhadap Belanja Daerah (Studi Kasus di Pemerintah Daerah Kabupaten/Kota Provinsi Jawa Barat), Jurnal Ilmiah EDUKASI Volume. 5 Nomor 2, Program Studi Akuntansi Fakultas Ekonomi Universitas Galuh Ciamis 